\title{
Downburst-producing thunderstorms in southern Germany: Radar analysis and predictability
}

\author{
Nikolai Dotzek $^{\mathrm{a}, \mathrm{b}, *}$, Katja Friedrich ${ }^{\mathrm{a}, 1}$ \\ a Deutsches Zentrum für Luft- und Raumfahrt (DLR), Institut für Physik der Atmosphäre, Oberpfaffenhofen, 82234 Wessling, Germany \\ b European Severe Storms Laboratory (ESSL), Münchner Str. 20, 82234 Wessling, Germany
}

\section{A R T I C L E I N F O}

\section{Article history:}

Received 14 December 2007

Received in revised form 5 September 2008

Accepted 26 September 2008

\section{Keywords:}

Downburst

Polarimetric bistatic radar

WINDEX

GUSTEX

\begin{abstract}
A B S T R A C T
Three days with downburst-producing thunderstorms during the VERTIKATOR intensive observation period in June and July 2002 are studied by means of the C-band polarisation diversity radar POLDIRAD and its network of three bistatic receivers. We present the first wind vector fields from a downburst measured by such a bistatic network. The polarimetric radar data allowed testing the recent hypothesis that a dominant trigger mechanism for wet downbursts might be the cooling due to melting of small hail or graupel in the storm, and we found some evidence for this process in the VERTIKATOR storms. This could be exploited by polarimetric radar nowcasting algorithms for downburst detection. The predictability of the downburst potential was further investigated from proximity soundings and their derived indices WINDEX as well as different formulations of GUSTEX. In particular, a new formulation of GUSTEX is proposed here which shows promising predictive skill for the VERTIKATOR cases and a number of other severe (and non-severe) situations from the same region in southern Germany.
\end{abstract}

(c) 2008 Elsevier B.V. All rights reserved.

\section{Introduction}

Downbursts as a special class of straight-line wind events present a considerable hazard not only to property and human lives, but in particular to aircraft during take-off and landing (cf. Fujita, 1981, 1985; Fujita and McCarthy, 1990; Doswell, 2001). Due to their higher frequency of occurrence, they easily outweigh the threat posed by tornadoes, even though that exists in Europe as well (e. g., Roach and Findlater, 1983; Bech et al., 2007).

The common terminology classifies downbursts into the sub-categories microburst and macroburst, where the latter term is used if the areal extent of the wind damage exceeds $4 \mathrm{~km}$ (the threshold between misoscale and mesoscale, Fujita, 1981). Yet, throughout this paper which analyses both micro-

\footnotetext{
* Corresponding author. DLR-Institut für Physik der Atmosphäre, Oberpfaffenhofen, 82234 Wessling, Germany. Tel.: +49 815328 1845; fax: +49 8153281841 .

E-mail address: nikolai.dotzek@dlr.de (N. Dotzek).

URL: http://essl.org/people/dotzek/ (N. Dotzek).

1 Present affiliation. ATOC, University of Colorado at Boulder, UCB 311, Boulder, CO 80309-0311, USA.
}

and macroburst cases, we will mainly use the generic term "downburst". A further phenomenological distinction is made between dry downbursts (e. g., Wakimoto, 2001) and wet downbursts (e. g., Fujita, 1985). Wet downbursts are characterised by heavy precipitation at the ground, either rain or hail. Dry downbursts only require light precipitation at the level of downdraft initiation which quickly evaporates during descent of the air mass, such that usually no precipitation reaches the ground. This makes early detection of dry downbursts using Doppler radars and eye observations quite difficult and enhances the threat that they pose to low-flying aircraft. However, dry downbursts are apparently very rare events in Central Europe, as they require the presence of very deep and nearly adiabatic subcloud layers which are seldom present in this region. To the authors' knowledge, dry downburst reports in Europe are currently anecdotal, at best.

Wet downbursts, like the cases we present here, are easier to detect both by radar and by eye due to their dense precipitation core. Nevertheless, the distinction between a rain shaft with or without high winds strongly depends on the thermodynamic stratification of the air mass and on the presence of a layer with 
high horizontal momentum near the level of downdraft initiation. Relying solely on the visual or radar appearance of an intense thunderstorm does not easily allow for a decision if high winds have to be expected from it. This may lead to warnings being issued too late (or not at all) and consequently to damage at the ground which could have been avoided or mitigated in principle. Faust (1948) describes a significant wet downburst on 13 July 1941, affecting what is nowadays Frankfurt international airport with little prior warning and leading to the destruction of 40 aircraft at the ground.

In general, downbursts of a given intensity occur more frequently and their damage swaths also tend to affect larger areas than those of equally intense tornadoes. For this reason, it is important to study the life-cycles of downburstproducing thunderstorms over both flat and complex terrain to detect possible differences and to investigate their predictability from routinely available observations like radiosonde ascents and weather radar observations.

Polarimetric Doppler radar is ideally suited for the analysis of the life-cycles and for the development of nowcasting methods. A special opportunity to study downburst events was provided by the VERTIKATOR project (www.vertikatorafo2000.de), which aimed at an improved understanding of initiation and development of shallow and deep convection over mountainous terrain. Interaction of synoptic scale settings with local effects like the heat low over mountain ranges or valley flows on convective transport was a major focus. During the VERTIKATOR intensive observation period (IOP) in summer 2002, one investigation area was located in the northern Alpine Foreland between Munich, Germany, and Innsbruck, Austria (cf. www.pa.op.dlr.de/vertikator/). A great variety of observations were made, involving several aircraft, radars, lidars, sodars, and a surface mesonet. In addition, routine observations from radiosondes, satellites and cloud-to-ground (CG) lightning data from the BLIDS network (with sensors similar to the NLDN in the USA, cf. Cummins et al., 1998) are available.

During the VERTIKATOR IOP in June and July 2002, several wet downbursts were observed in the northern Alpine foreland within about $50 \mathrm{~km}$ radius from the polarisation diversity radar POLDIRAD operated by the German Aerospace Centre DLR. This is a region of Germany with a high frequency of thunderstorms (30 to 35 thunderstorm days per year, see Bissolli et al., 2007), often accompanied by hail or straight-line winds (Koschmieder, 1944; Meischner et al., 1991; Höller, 1994; Höller et al., 1994), for which the infamous Munich hailstorm of 12 July 1984 (Heimann and Kurz, 1985; Höller and Reinhardt, 1986) is an example with a total damage close to 1 billion EUR. In this paper, we will analyse (bistatic) polarimetric Doppler radar data from the VERTIKATOR IOP events and use the observations to test recent findings by Atlas et al. (2004) emphasizing the role of melting small hail for initial downdraft formation.

Another aspect in studying severe local storms is to investigate their predictability using radar-based nowcasting tools or numerical simulations. Potential impacts by global climate change on the frequency, size and intensity of these events are also being studied extensively. As a contribution to the ongoing project RegioExAKT (www.regioexakt.de) aside from the radar nowcasting aspect - we will investigate in the second part of this study the predictability of the VERTIKATOR downbursts (and related cases) based on different formulations of the WINDEX (McCann, 1994) and
GUSTEX (Geerts, 2001) indices. Our motivation to use these was that both parameters can be derived with little computational effort from operational atmospheric soundings and thus can be routinely made available shortly after completion of a sounding. A further motivation to test parameters like these is that they can also be derived from reanalysis data (cf. Brooks et al., 2003, 2007) or regional climate model runs for climate change scenarios. This will allow for a statistical comparison between the "index climatology" now and in the future scenario.

Our paper is organised as follows: Section 2 provides the necessary background information on downburst climatology and formation mechanisms. Three downburst-producing thunderstorms are exemplarily analysed in Section 3, while Section 4 investigates the predictability of the downbursts events and compares the VERTIKATOR events to other case studies, either in the same region (Dotzek et al., 2001; Fehr et al., 2005; Dotzek et al., 2007) or even affecting larger parts of Germany (Gatzen, 2004). Sections 5 and 6 present discussion and conclusions.

\section{Downburst climatology and formation mechanisms}

\subsection{Downburst climatology in Germany}

In order to assess how representative the present downburst cases are, it is necessary to review the German downburst climatology first. This will show if the 2002 downbursts were typical events or more exceptional, and provides a basis for comparison to the German tornado climatology recently investigated by Dotzek et al. (2000) and Dotzek (2001, 2003). Fig. 1 shows the German downburst climatology using all TorDACH storm reports up to 2005 (version 1.6). An earlier version of that database was analysed by Dotzek et al. (2007, their Fig. 1) and can be compared to the augmented data used here. By now, the TorDACH data have been included in the European Severe Weather Database (ESWD, www.essl.org/ESWD/, cf. Dotzek et al., 2009-this volume). Since 2006, severe storm events from Germany are only recorded in the ESWD.

Downbursts in Germany are almost exclusively of the wet downburst type. Fig. 1a illustrates the evolution of downburst reporting in Germany. Their recording mainly began around 1880 , in context of the work leading to the monograph by Wegener (1917). Until 1940, the reporting ranged between 30 to 60 reports per decade. This level was later only exceeded in the 1950s and 1980s. Recently both the activity of the TorDACH network and the widespread availability of online news, weather fora as well as renewed interest in severe convective storms research in Europe (see Snow, 2001, 2003; Dessens and Sanchez, 2007 ) led to a boost in reports to nearly 80 per year since 2000 . The total number of wind reports in the final TorDACH data is 1019, of which 705 date from the period 1950-2005.

The diurnal cycle is given in Fig. 1b. Peak activity is limited to the afternoon and evening hours, with some further activity during the night, resembling the thunderstorm daily cycle (cf. Wegener, 1917). The downbursts during VERTIKATOR occurred in the afternoon or evening, so with this respect, the present cases are quite typical. The annual cycle of downbursts is given in Fig. 1c for each month. A dominant July maximum of downburst activity is obvious. Generally, from 

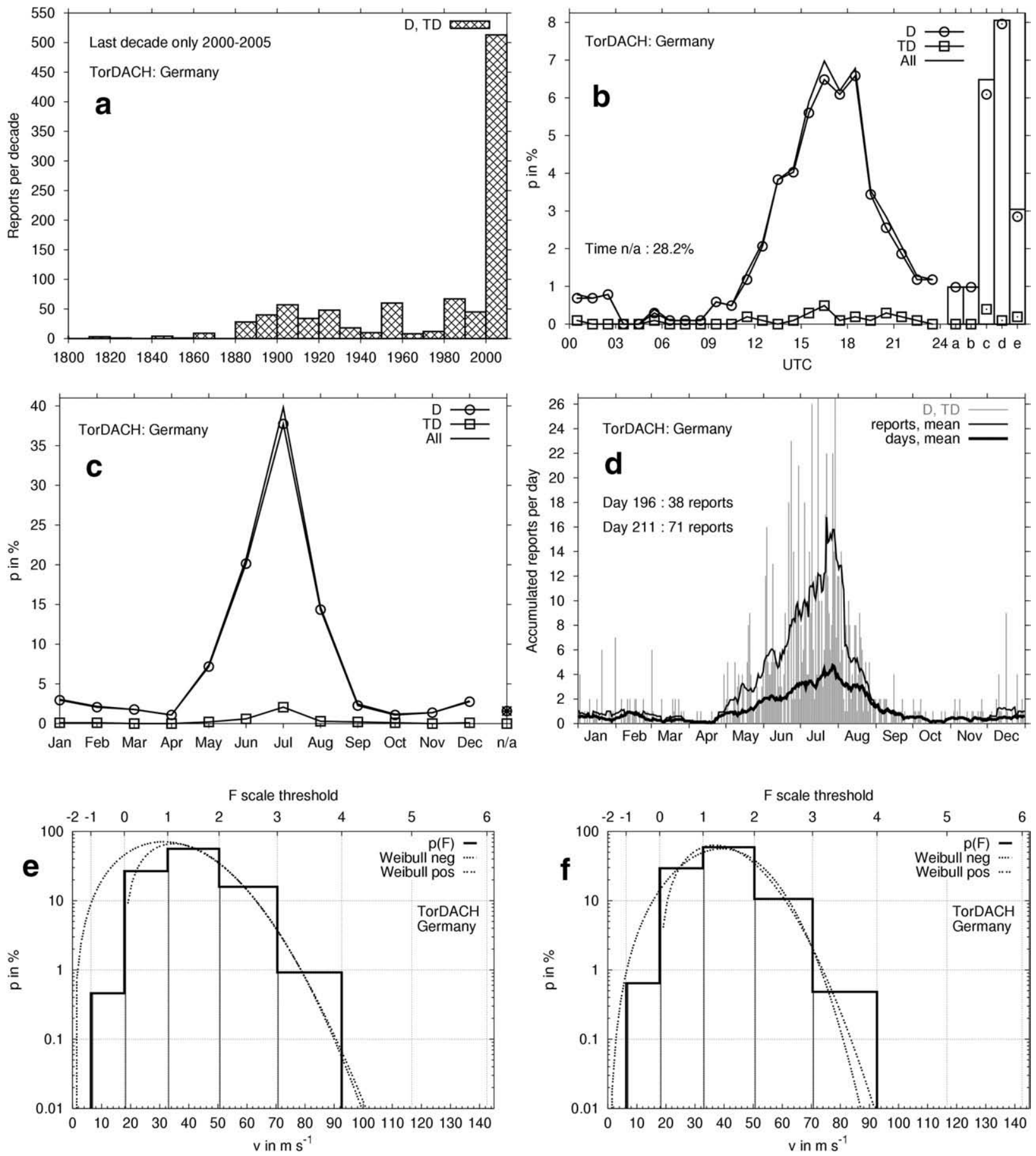

Fig. 1. Climatological analysis of downbursts in Germany derived from TorDACH data V1.6. (a) decadal time series from 1880 to 2005 , (b) diurnal cycle. Here, the bars above labels a-e denote the diurnal cycle for cases in which time was only reported as "morning”, "midday", "afternoon", "evening", or "night", respectively. (c) Provides the annual cycle by months and by days (d). Accumulated reports per day are shown as impulses, 15-day running averages depict the annual cycles of downburst days (bold) and downburst reports (thin). The downburst intensity distribution over F-scale is shown for all rated cases (e) and for the period $1950-2005$ only (f). The data also contain an insignificant number of cases which may have been either downbursts or tornadoes (labelled TD).

May to August, the chances for downbursts to occur are significant, also resembling the thunderstorm annual cycle. There is a weak secondary maximum in mid-winter, likely related to embedded thunderstorms within the fronts of extratropical cyclones. The VERTIKATOR downbursts consid- ered here and by Dotzek and Friedrich (2003) are thus typical, whereas Dotzek et al. (2007) studied a case of March 2001 from the months with the lowest percentage of downburst reports - and which will serve as a comparative example here. 
By plotting accumulated numbers of reports for each day and by showing running averages of days with at least one downburst and the total number of reports, Fig. 1d provides the annual cycle in a different way. Where the curves show a spread, multiple downburst reports are available for a particular day. The peak of downburst days and downburst reports is found in late July, with a steep decline afterwards. Also downburst report multiplicity continuously increases from late April to late July, and nearly vanishes by late August.

Finally, Fig. 1e,f shows intensity distributions for downbursts as a function of both Fujita's F-scale (Fujita, 1971, 1981; Fujita and Pearson, 1973) and the corresponding wind speeds. The empirical distributions were modelled by Weibull distributions (Dotzek et al., 2003, 2005; Feuerstein et al., 2005) shown by the smooth curves.

While tornado reports in Germany are present up to F5 intensity on the F-scale, (cf. the intensity distributions shown by Dotzek, 2001; Dotzek et al., 2005), the downbursts in Fig. 1e,f are limited to the range up to F3, consistent with findings from the USA (e. g., Fujita, 1981, 1985). Cases of F1 and F2 intensity make up the majority of reports. Note that in Fig. 1e, the percentage of $\mathrm{F} 3$ events among all recorded downbursts with intensity rating is higher than in Fig. 1f which includes only events from 1950-2005. This is a typical feature of extreme event climatologies and comes from the fact that historic descriptions of such events are usually biased towards the most extreme ones, thus under-representing the weak cases (cf. Brooks and Doswell, 2001, illustrating this for the French tornado record). Therefore, Fig. $1 \mathrm{f}$ is likely to be closer to the "true" climatology, at least for the significant downbursts (F2 or stronger).

Summing up the climatological findings, both with regard to their months and hours of occurrence, as well as concerning their intensity, the VERTIKATOR downbursts with F1 and F2 on the F-scale are not exceptional. Thus, they can now be compared to other summer cases presented by Dotzek et al. (2001) and Fehr et al. (2005).

\subsection{Downburst formation mechanisms}

The formation of dry and wet downbursts has been a subject of research for several decades. Aside from radar case studies (e. g., Wakimoto and Bringi, 1988; Vivekanandan et al., 1990; Scharfenberg, 2002, 2003; Atlas et al., 2003) or surveys of ground damage tracks (e. g., Letzmann, 1939; Fujita, 1985; Dessens and Blin, 1988; Peterson, 1992a,b; Hubrig, 2004; Dotzek et al., 2008), the microphysical processes leading to the formation of strong convective downdrafts have been investigated for instance by Suckstorff $(1935,1938)$, Kamburova and Ludlam (1966), Srivastava (1985, 1987), Doswell (1993), Emanuel (1994), and reviewed by Cotton and Anthes (1989), Houze (1993), Wakimoto (2001) and Markowski (2002).

From these, the following processes can be identified as conducive for downdraft formation or its intensification to downburst intensity:

1. a deep, well-mixed (near-adiabatic) planetary boundary layer, or a superposition of separate well-mixed layers, like a convective boundary layer with a second near-adiabatic layer on top which may have been advected from a region with elevated terrain;
2. a decrease of moisture towards the ground within the well-mixed layer(s), leading to a characteristic "triangle shape" of the temperature and dewpoint curves in thermodynamic diagrams;

3. a forcing mechanism triggering the initial convective downdraft. This may be isobaric cooling due to evaporation of cloud droplets or raindrops, or by melting of frozen hydrometeors at or below the melting layer. Another effect could be the direct hydrometeor drag or loading by large raindrops or hailstones;

4. the presence of high winds at or above the downdraft initiation altitude can lead to further enhancement of the potentially damaging winds at the surface, as the high momentum aloft may be advected to the ground by the downdraft (e. g. McCann, 1994; Geerts, 2001).

From the processes listed above, especially the melting of hydrometeors (no. 3) has received much attention. Kamburova and Ludlam (1966) had noted that smaller hydrometeors contribute most to the cooling by evaporation or melting, as these expose a larger total surface to the surrounding air for a given hydrometeor content. The microphysical model by Srivastava (1987) emphasized the role of melting small hail for downdraft initiation, while Atlas and Williams (2003) and Atlas et al. (2004) provided evidence from profiler radar observations that this is indeed an important process. Melting hail can be detected in polarimetric radar data from several quantities. First, wet hailstones can be distinguished from raindrops or dry hailstones by their unique relation between reflected energy and polarisation of the radar beam versus particle size or surface characteristics (frozen/liquid). Quantitatively, this can be expressed by reflectivity at horizontal polarisation $\left(Z_{h}\right)$, ratio between horizontal and vertical reflectivity (i.e. differential reflectivity, ZDR), and linear depolarisation ratio (LDR) for horizontal transmit and vertical receive (and vice versa). Second, melting hailstones accrete a ringshaped coating of water due to the airflow around the particle during its fall to the ground. Melting hail has an oblate shape compared to quasi-spherical dry hailstones leading to enhanced values of ZDR, exceeding about $2 \mathrm{~dB}$.

So from the three thermodynamic processes listed above, operational radiosonde data from Munich (WMO station 10868 in Fig. 2) located $\sim 25 \mathrm{~km}$ northeast of the radar will be used to describe the atmospheric stratification and moisture content (conditions 1 and 2) prior to downdraft formation. Melting of hail (ingredient 3 ) will be monitored using polarimetric radar measurements. The fourth process, advection of high momentum from above, is dynamical and will be determined combining wind measurements from atmospheric soundings and the bistatic Doppler radar network (Fig. 2).

\section{VERTIKATOR cases}

This section presents a radar analysis of the evolution of storms during the VERTIKATOR campaign in which severe hail and wind damage occurred at the ground: According to the TorDACH storm reports, all storms studied here had both damaging straight-line winds and large hail. On all three days, thunderstorms first formed over the northern Alps and then moved rapidly towards the northeast into the observational area (Fig. 2a): On 20 June 2002, F0 microbursts occurred from 
a

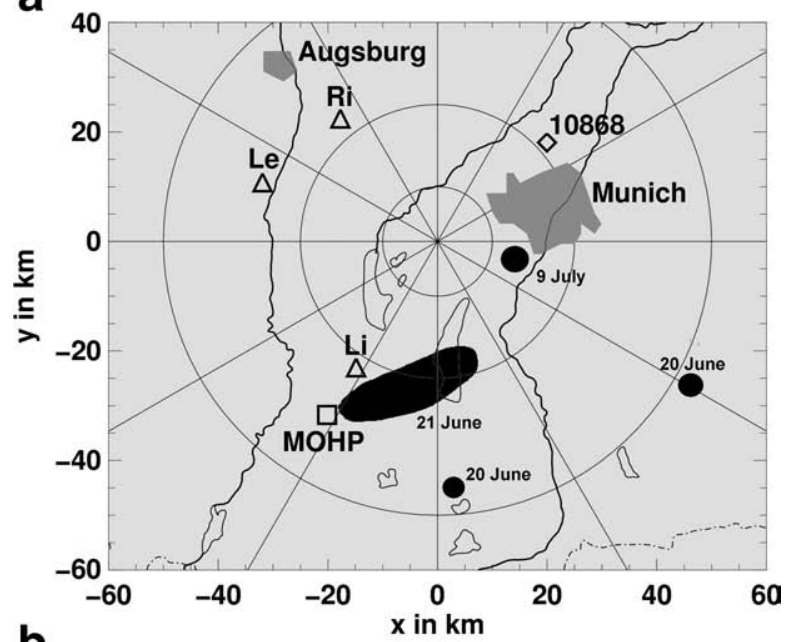

b

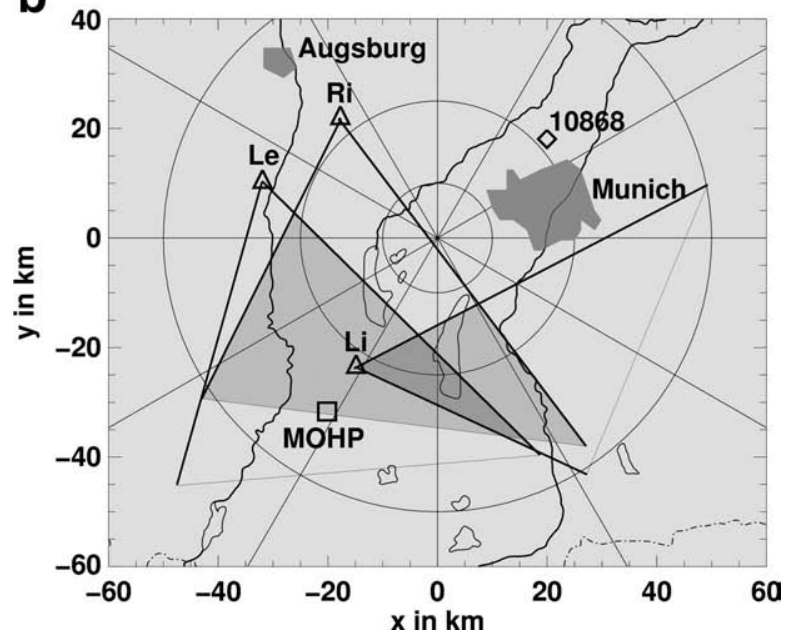

Fig. 2. (a) Maps of the VERTIKATOR observation area, with DLR's POLDIRAD and Oberpfaffenhofen airport at the origin. Range rings are drawn at 10, 25 and $50 \mathrm{~km}$ from the radar. Cities Munich and Augsburg are shown, as well as the Munich radiosonde station 10868, the meteorological observatory Hohenpeißenberg (MOHP) and DLR's three bistatic receiver sites Ried, Lechfeld and Lichtenau. Filled black areas illustrate the downburst damage areas. In (b), the $60^{\circ}$ aperture angles of the three bistatic receivers are sketched. Grey-shading reflects aperture overlap and corresponds to the number of individual wind components available (medium grey $=2$ components, dark grey $=3$ components).

isolated storms south and southeast of the radar at about $50 \mathrm{~km}$ range. One day later, an F1 macroburst developed from a longer-lived storm. The area of downburst damage was located $25 \mathrm{~km}$ south of the radar. On 9 July, of several storms which later merged into a linear system, one with supercell characteristics produced an F1 microburst southwest of Munich at $\sim 15 \mathrm{~km}$ range from the radar. Fig. 2a illustrates the location of these events in the radar reference frame, and Table 1 provides a synopsis of the basic convective parameters on the days studied here, as well as for some other events which will be studied in Section 4 .

The platform to study the VERTIKATOR storms was the C-band ( $5.5 \mathrm{~cm}$ wavelength) polarisation diversity Doppler radar POLDIRAD at DLR (Schroth et al., 1988). It provided three-dimensional information on thunderstorm dynamics
Table 1

Basic parameters from 1200 UTC soundings at WMO stations Munich (10868), Stuttgart (10739) and Prague (11520): convective available potential energy (CAPE), convective inhibition (CIN), bulk Richardson number $\left(R i_{\mathrm{b}}\right)$, level of free convection (LFC), level of neutral buoyancy (LNB), as well as the maximum surface temperature $T_{\mathrm{s}, \max }$ during the day. In column LFC, the values with asterisk are lifted condensation levels (LCL), as CAPE was diagnosed to be zero here. The only day without any significant weather was 8 July 2002, which serves as a null case here.

\begin{tabular}{llccclll}
\hline $\begin{array}{l}\text { Date, UTC } \\
\text { yymmdd, hh }\end{array}$ & $\begin{array}{l}\text { Station } \\
\text { WMO no. }\end{array}$ & $\begin{array}{l}\text { CAPE } \\
\text { in J kg }\end{array}$ & $\begin{array}{l}\text { CIN } \\
\text { in J kg }\end{array}$ & $\begin{array}{l}R i_{\mathrm{b}} \\
\text { in } 1\end{array}$ & $\begin{array}{l}\text { LFC } \\
\text { in hPa }\end{array}$ & $\begin{array}{l}\text { LNB } \\
\text { in hPa }\end{array}$ & $\begin{array}{l}T_{\text {s,max }} \\
\text { in }{ }^{\circ} \mathrm{C}\end{array}$ \\
\hline 840712,12 & 10868 & 399.6 & -28.4 & 3.94 & 795.5 & 269.7 & 28.3 \\
980721,12 & 10868 & 531.3 & -116.0 & 11.94 & 680.6 & 262.6 & 34.5 \\
010323,12 & 10739 & 0.0 & 0.0 & 0.0 & $885.6^{*}$ & n/a & 14.3 \\
010323,12 & 10868 & 0.0 & 0.0 & 0.0 & $872.4^{*}$ & n/a & 15.0 \\
020620,12 & 10868 & 538.5 & -257.0 & 27.89 & 647.9 & 217.8 & 31.0 \\
020621,12 & 10868 & 910.0 & -124.0 & 19.77 & 722.3 & 220.2 & 32.0 \\
020708,12 & 10868 & 0.0 & 0.0 & 0.0 & $788.2^{*}$ & n/a & 31.0 \\
020709,12 & 10868 & 939.1 & -108.0 & 40.29 & 678.4 & 229.9 & 33.5 \\
020710,12 & 10868 & 1164.0 & -79.9 & 19.54 & 755.9 & 236.1 & 30.0 \\
020710,12 & 11520 & 2198.0 & -6.7 & 114.9 & 803.6 & 211.6 & 30.0 \\
\hline
\end{tabular}

and microphysics, allowing for identification of different hydrometeor types in the thunderclouds and their anvil regions. Additional bistatic receiver locations at Ried, Lechfeld, and Lichtenau (cf. Fig. 2a,b and Friedrich, 2002) simultaneously measured several individual wind components. So the wind vector field could be determined within the shaded regions in Fig. $2 \mathrm{~b}$ in real-time. The 21 June downburst passed right through the optimal bistatic sector (dark-grey shaded area in Fig. 2b). In situations like these, with stronger winds, a dealiasing of the Doppler measurements by the bistatic POLDIRAD network is required and was described in detail by Friedrich and Hagen (2004) or Friedrich and Caumont (2004).

During the VERTIKATOR Alpine IOP, life cycles of a variety of thunderstorms were observed and analysed, for instance for their hydrometeor distribution. POLDIRAD's hydrometeor classification was developed by Höller et al. (1994) and Höller (1995, cf. Fehr et al., 2005) and recently modified by Friedrich and Caumont (2004). This will be exploited to test the hypothesis by Atlas et al. (2004) that the melting of small hail is the most important trigger in downburst initiation. Could it be corroborated by finding either small, wet or large, dry graupel as well as small, dry hail or any wet hail (hydrometeor classes 4,6 and 8 in Table 2) in the area of microburst formation, it would help to optimise microburst nowcasting

Table 2

POLDIRAD hydrometeor classification (Friedrich and Caumont, 2004) based on the original formulation by Höller et al. (1994) and Höller (1995).

\begin{tabular}{rrl}
\hline 1 & $\square$ & Small raindrops (below melting level) \\
2 & $\square$ & Large raindrops \\
3 & $\square$ & Graupel (dry, small), snow (above melting level) \\
4 & $\square$ & Graupel (wet, melting, small), graupel (dry, large), hail (dry, small) \\
5 & $\square$ & Hail (dry) \\
6 & $\square$ & Hail (wet) \\
7 & $\square$ & Large wet hail (water shell) \\
8 & $\square$ & Rain and small hail (wet) \\
9 & $\square$ & Rain and large hail (wet) \\
10 & $\square$ & Undefined (scanned, no hydrometeor classification) \\
11 & $\square$ & Large wet hail (spongy) \\
12 & $\square$ & Hail spike (multi-body scattering) \\
13 & $\square$ & Propagation effects \\
14 & $\square$ & Hail spike and propagation effects \\
\hline
\end{tabular}


algorithms based on polarimetric radar data. Larger dry hail (hydrometeor class 5 in Table 2) is also a candidate hydrometeor for downdraft initiation if it is found near or below the freezing level.

\subsection{F0 microbursts: 20 June 2002}

Thunderstorms on this day were relatively short-lived and occurred out of the field of view of the bistatic POLDIRAD receivers (Fig. 2b). So for this day, only the radial velocity and polarimetric quantities $Z_{\mathrm{h}}, Z D R$, and LDR are available. However, some of the weak downbursts on this day have also been documented by storm chasers, so radar and ground observations can be compared.

Fig. 3a shows the 1200 UTC (local time was UTC $+2 \mathrm{~h}$ ) Munich sounding and reveals a layer with steep lapse rates between 850 and $650 \mathrm{hPa}$. The humidity in this layer is far from saturation, and observed surface dewpoints peaked at about $23{ }^{\circ} \mathrm{C}$, exceeding the radiosonde surface value. Passage of an upper-level shortwave trough was forecast for the afternoon (Freuer, 2002). However, neither the overall thermodynamic conditions for downbursts (cf. Section 2.2) nor for severe thunderstorm formation (e.g. strong wind shear in the lowest kilometres AGL) was ideally met, as also

\section{a}

10868 Muenchen-Oberschlssheim

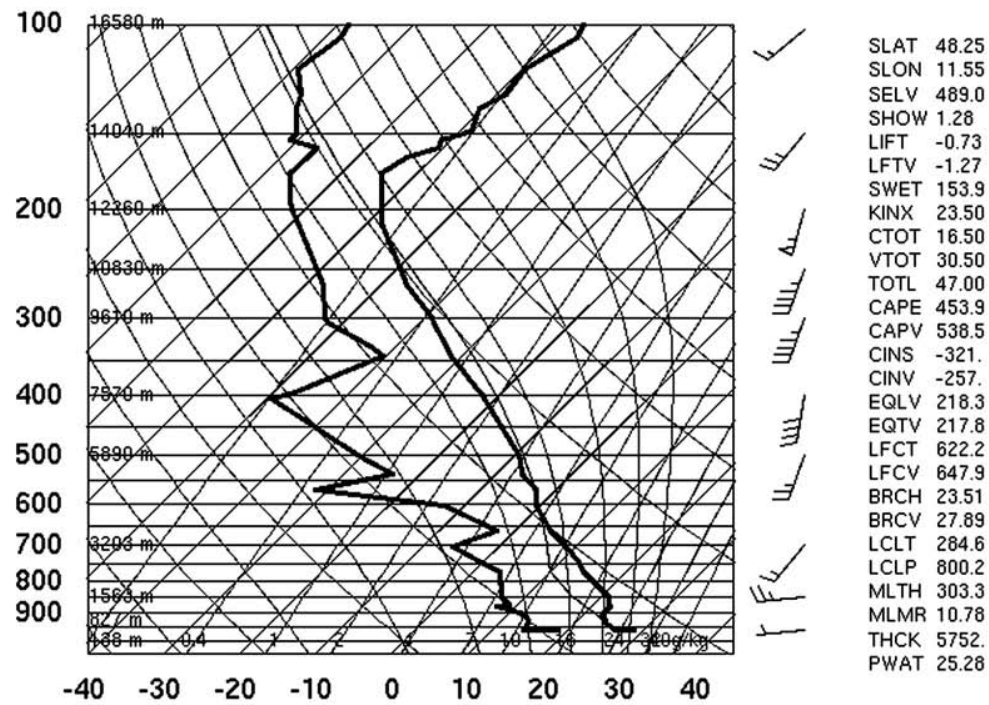

$12 Z 20$ Jun 2002

University of Wyoming

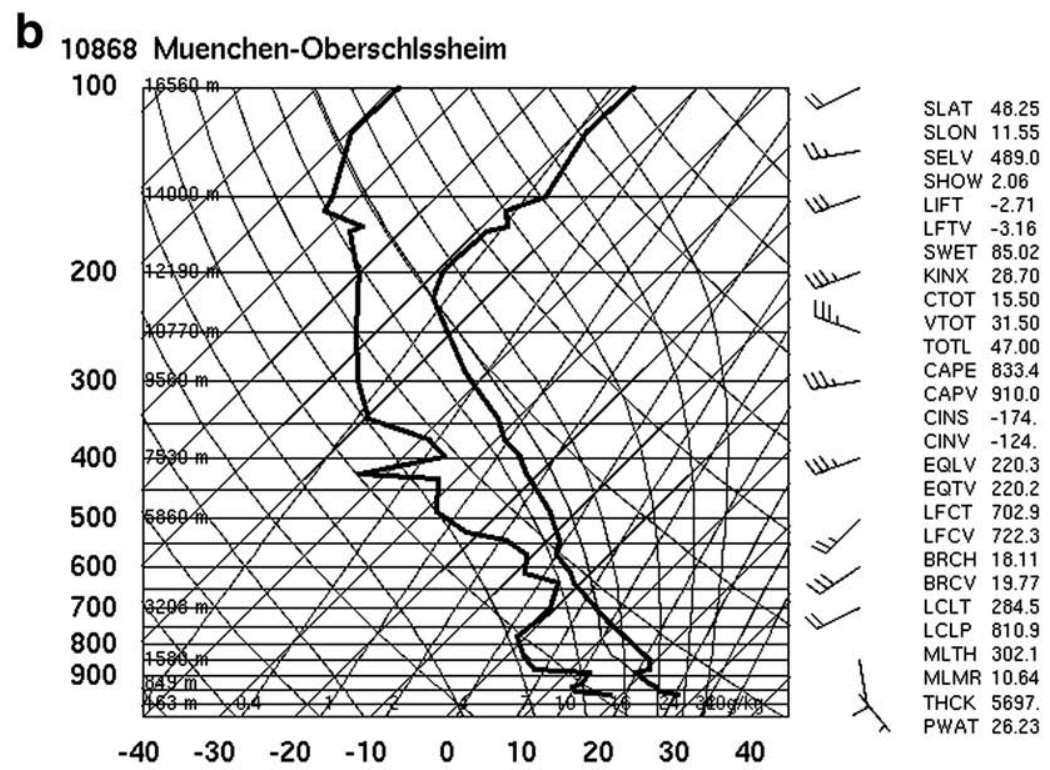

$12 Z 21$ Jun 2002

University of Wyoming

Fig. 3. Munich soundings of 20 June 2002, 1200 UTC (a) and 21 June 2002, 1200 UTC (b), courtesy of the University of Wyoming. 
the wind shear at mid- to upper-tropospheric levels was mainly unidirectional, with backing winds at low levels indicative of cold air advection, damping the thunderstorm initiation from the upper-level forcing. So it is plausible that only weak F0-downbursts occurred on this day.

Nevertheless, some storms were able to attain echo tops exceeding $13 \mathrm{~km}$ AGL (Fig. 4a). The cell shown here is typical for the storms developing on this day. There is a tall, narrow reflectivity core peaking at $60 \mathrm{dBZ}$ which overshoots the anvil level considerably. The hydrometeor distribution in Fig. 4b accordingly classifies the core region of the storm as dominated by large hail, and by large raindrops in the transition zone towards the stratiform anvil region (classes 5 and 8 in Table 2). Regions with small or melting hail (class 4 in Table 2) make up only a small fraction of the radar volume, however hydrometeor classes 4, 6 and 8 can be found on the downstream side of the storm next to the precipitation core below about $3 \mathrm{~km}$ AGL.

The most notable hailstorm of this day occurred later on and reached its highest intensity at approximately 1540 UTC, when storm chasers documented hail of a size up to $3 \mathrm{~cm}$ on the ground, sometimes piled up $15 \mathrm{~cm}$ high. Yet, the corresponding microburst winds from this cell only reached F0 intensity. Typical severe storm structures were also observed $\sim 55 \mathrm{~km}$ southeast of POLDIRAD at 1542 UTC (Fig. 5) with peak reflectivity at $\sim 60 \mathrm{dBZ}$ and a hailspike (a multi-body scattering signature typical of large hailstones). At this range, the radar beam is at about $3 \mathrm{~km}$ AGL. Radar observations match well to the storm chaser reports of large hail. From their ground observations, the region of the downburst seems to have been limited to the northwest flank of the cell, below a zone with smaller reflectivity.

The Doppler velocity in Fig. 5b reveals that in this region, a mesocyclonic vortex signature (MVS) was combined with a weak convergence pattern. A (persistent and deep) mesocyclone is one of the general criteria for supercell thunderstorms. From the convergent vortex signature in the radial velocity field at $3^{\circ}$ elevation - being below the $0{ }^{\circ} \mathrm{C}$-level on that day - it can be hypothesized that at this level, horizontal confluence of air is induced by descending air in the downdraft below for reasons of continuity. The hydrometeor classification in Fig. $5 c$ provides evidence for the presence of melting graupel and smaller hail (classes 4 and 8 in Table 2) on the cell's flank towards the radar, while the cell core is indeed dominated by large hail (classes 57 in Table 2), as already suspected from the reflectivity field and the hailspike. While the storm contained a substantial amount of larger hail, also melting of small hail or graupel particles may well have contributed to the initiation of the downburst, which was later followed by the $3 \mathrm{~cm}$ hailstones at the ground from the storm's core.

\subsection{F1 macroburst: 21 June 2002}

Another short-wave trough reached southern Germany, and more vigorous storms developed on this day. This was likely due to stronger vertical wind shear and higher CAPE compared to 20 June (cf. Fig. 3 and Table 1) and the absence of low-level cold air advection. One hailstorm (maximum hailstone size $3-4 \mathrm{~cm}$ reported on the ground) produced a macroburst at about 1500 UTC, with an $18 \mathrm{~km}$ long, high-F1 damage swath $25 \mathrm{~km} \mathrm{SSW}$ of the radar location, affecting rural and urban areas. This storm moved right through the area of the bistatic receivers, which therefore yielded detailed near-surface wind fields in this downburst. This allowed diagnosing the wind speed some hundred meters AGL to be at or above $140 \mathrm{~km} \mathrm{~h}^{-1}$. From an aerial survey a few days after the event, similar to the one performed by Dotzek et al. (2007), the forest damage found and the wind swaths in crops are consistent with this velocity range in the middle of the F1 intensity class.

The potential for higher downburst intensities than on the day before can already be deduced from the 1200 UTC Munich sounding in Fig. 3b. Below $650 \mathrm{hPa}$, there are two well-mixed air masses with nearly adiabatic lapse rates. The lower layer, apparently the convective boundary layer of 21 June, reaches upward to about $900 \mathrm{hPa}$. The layer above probably still represents the conditions of the day before. Near $625 \mathrm{hPa}$, the air is almost saturated, but in both well-mixed layers, the moisture drastically decreases towards the ground. The possible formation of severe thunderstorms is also indicated by other parameters (Table 1 ). The convective available potential energy CAPE is $910 \mathrm{~J} \mathrm{~kg}^{-1}$, and the wind profile displays considerable cyclonic directional and velocity shear.

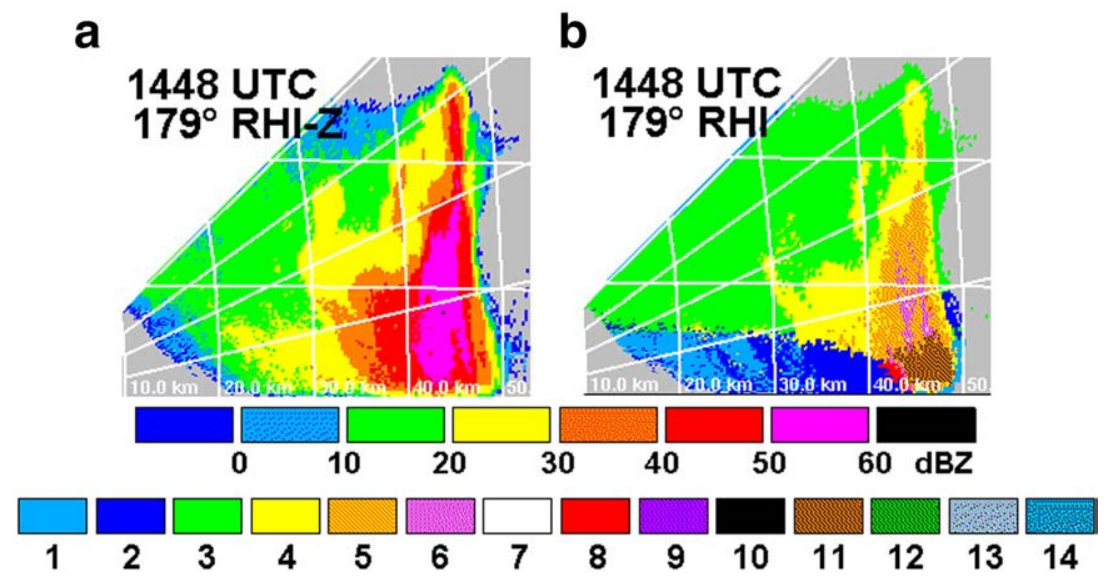

Fig. 4. RHI scans ( $179^{\circ}$ azimuth) at 1448 UTC of one of the early thunderstorms on 20 June 2002: (a) reflectivity, and (b) hydrometeor classification (key is shown in Table 2). The horizontal grid lines in the figure denote altitude levels $5 \mathrm{~km}$ and $10 \mathrm{~km}$ above radar (radar elevation is $602.5 \mathrm{~m} \mathrm{ASL}$ ). 

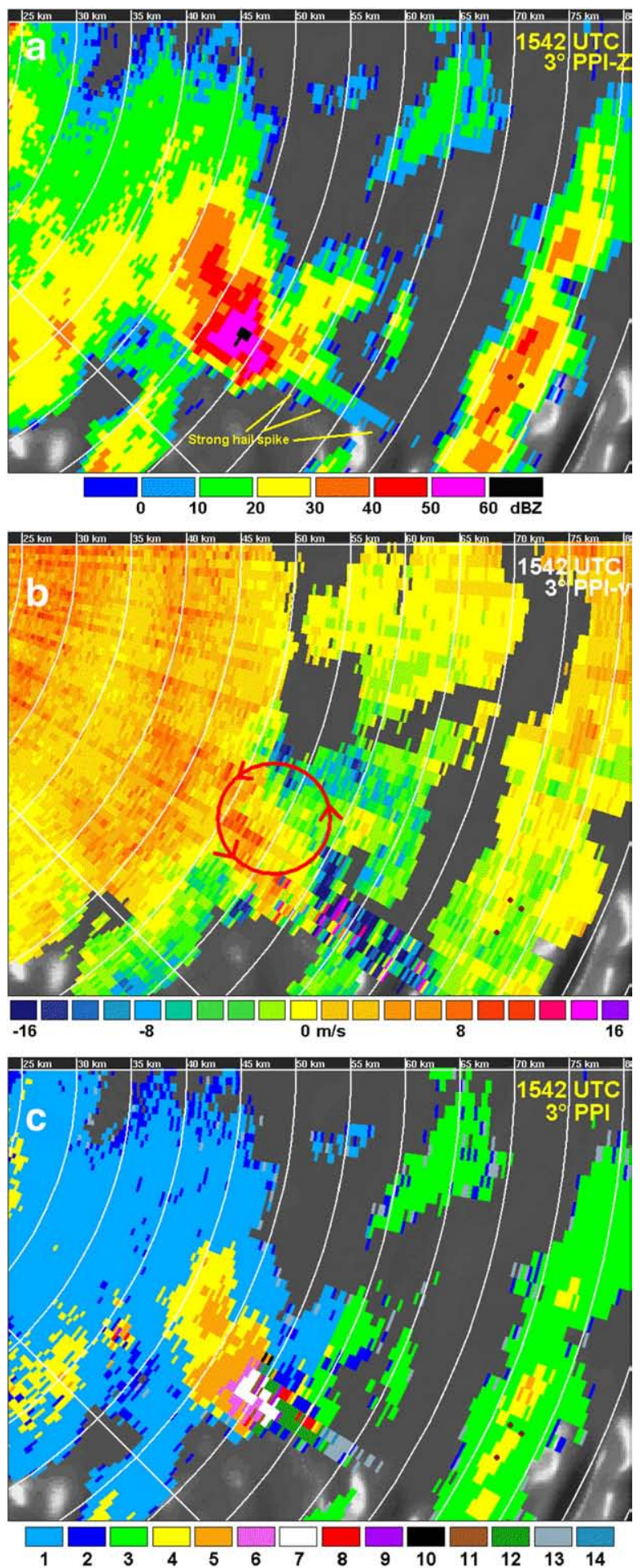

Fig. 5. PPI scans at $3^{\circ}$ elevation angle at 1542 UTC: (a) reflectivity, (b) Doppler velocity with slightly convergent mesocyclonic vortex signature, and (c) hydrometeor classification (cf. Table 2). Note the hailspike signature.

This yields a bulk Richardson number of $R i_{\mathrm{b}}=19.8$, in the range for possible supercell formation. The 1200 UTC sounding showed a capping inversion at about $900 \mathrm{hPa}$, and convective initiation over the Alps may have been elevated, while farther north of the Alps, the cap may have been eroded by the convective boundary layer in the afternoon.

Fig. 6a shows the reflectivity field at 1456 UTC. Shortly before, it had hit the Meteorological Observatory at Hohenpeißenberg, (MOHP, $1000 \mathrm{~m} \mathrm{ASL}$ ) which reported a wind maximum of $34.3 \mathrm{~m} \mathrm{~s}^{-1}$. Two individual storms can be seen in Fig. 6a, of which the western cell caused the downburst and hail up to 3-4 cm, while for the eastern cell $\sim 40-50 \mathrm{~km}$ southwest of the radar no detailed reports of wind damage are available. The eastern cell also was out of the bistatic network's field of view (Fig. 2b), so wind vectors could only be derived for the western cell ${ }^{2}$, for which Fig. 6a shows that a gust front precedes the northern flank of the storm by about $5 \mathrm{~km}$. The eastern cell also generates a gust front, which is however weaker than with the other storm.

A striking feature of the western cell is the apparent echofree notch to the south-southwest of its core. The radar beam is so much attenuated in this sector by the heavy precipitation and hail in the storm's centre that no signal is returned to the radar. Based on the time sequence of the radar images and the acquired polarisation data, the presence of an actual weakecho region could be excluded as a candidate to explain the echo-free region. Such strong attenuation is known to be a reliable sign of storm severity. At that time, the storm could well be seen from the DLR radar site and displayed a very dark forward flank. Based on the radar observations and its visual appearance, the air traffic control (ATC) at Oberpfaffenhofen airport was warned of the storm, and ATC advised the small aircraft flying at this time to land before the cell could directly affect the airport.

That the storm was indeed hazardous at this stage is further illustrated by the bistatic wind vectors at 1458 UTC in Fig. 6b. They reveal the downburst structure and peak at about $40 \mathrm{~m} \mathrm{~s}^{-1}$ from the southwest, that is, roughly in the direction of propagation, consistent with the observed high F1 forest damage in that region. Note that the peak wind vectors of the downburst's forward flank were oriented at an almost right angle to the POLDIRAD radials. Therefore, the true downburst intensity would have been hard to diagnose from the radial velocity field alone. Towards the south of the cell and at an elevation of $\sim 1.5 \mathrm{~km}$ AGL in Fig. 6b, the winds have already weakened, and an outflow towards the left and right flanks of the storm can be seen. Simultaneously, the stratiform region of the western cell already starts to merge with the storm to the east. Half an hour later, both cells had merged nearly completely but at the same time decreased much in intensity.

Only the PPI scans of this day provide the full set of polarimetric parameters for testing the Atlas hypothesis for downburst initiation. In addition, due to the dense precipitation core of the western cell, the radar beam is strongly affected by attenuation. Thus, the interpretation of the hydrometeor classification must be performed very carefully (cf. Zrnić et al., 2000). However, some evidence for the presence of a mixture of rain and small hail is found at the

\footnotetext{
2 For completeness, we note that the storms on 21 June showed inhomogeneous directions of propagation. The western cell first moved to the north-northeast and turned right to the northeast after the downburst. The eastern cell moved to the north-northwest and thus quickly merged with the western cell after 1500 UTC. Other thunderstorms north of Munich (not shown) moved more or less from west to east.
} 

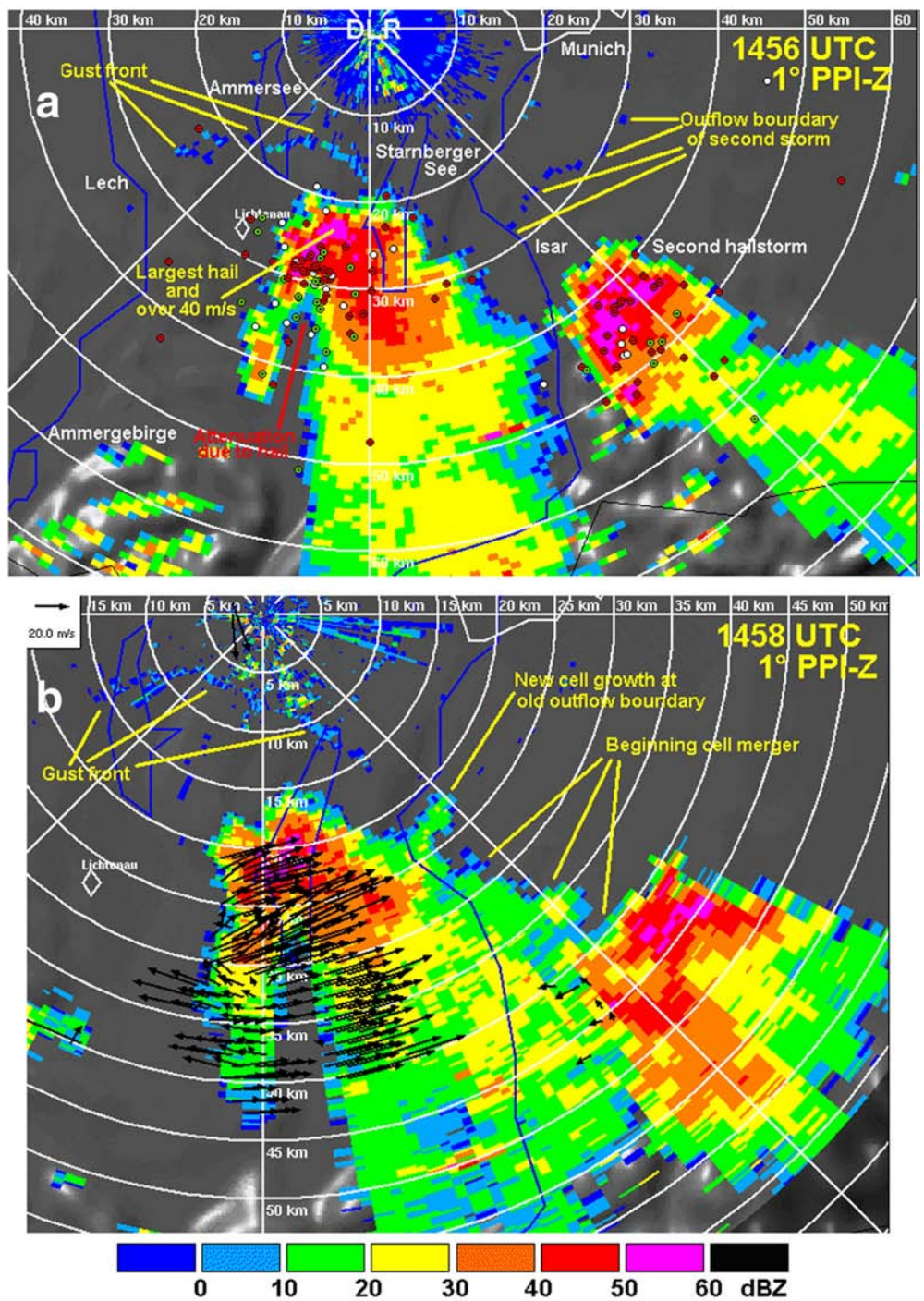

Fig. 6. PPI at $1.1^{\circ}$ elevation angle of radar reflectivity factor measured at (a) 1456 and (b) 1458 UTC during the downburst on 21 June 2002 . In (a), BLIDS lightning locations are plotted as small filled circles ( $r e d=C G-$, green $=C G+$, white $=$ intracloud). In (b), arrows indicate dealiased horizontal wind vectors derived from the bistatic network (cf. Fig. 2).

forward flank of the downburst-producing thunderstorms, so we cannot exclude that melting processes may have played a significant role in the creation of the initial downdraft.

\subsection{F1 microbursts: 9 July 2002}

The period from 8 to 10 July 2002 formed the main evaluation period for the VERTIKATOR Alpine field campaign, marking the transition from a hot, clear-sky period with a strong Alpine heat low until 8 July, to the formation of isolated severe storms on 9 July, and to a squall-line and later on derecho-producing situation on 10 July (Gatzen, 2004).

On 9 July, storms developed in the warm sector air mass ahead of a cold front crossing Europe. At 1200 UTC, convection developed within the northern Alps. The first convective cells propagated north-easterly into the Alpine Foreland a few hours later, reaching the radar observation area (Fig. 2) at about 1500 UTC. The city of Munich was affected around 1730 UTC, and cell mergers started at about 1800 UTC. Storms continued until after 2100 UTC, then showing very many impressive long-range intracloud lightning flashes in the anvil region.

Hail up to $3 \mathrm{~cm}$ size and several F1 microbursts occurred over southern Germany, leading to railway blockings caused by downed trees, for instance. The high downburst potential of that day is visible in Fig. 7 from the Munich sounding change from 1200 UTC (a) to 1800 UTC (b). The second sounding roughly corresponds to the time when the thunderstorms were over Munich, and the main downburst event southwest of the city had occurred about half an hour before, bringing $\mathrm{F} 1$ forest damage and $3 \mathrm{~cm}$ hail. The sounding evolution closely follows the examples given by Wakimoto (2001) for dry and wet microburst environments.

At 1800 UTC, there is an almost saturated layer at about $575 \mathrm{hPa}$ from which the temperature increases nearly dryadiabatically towards the ground, in particular below $750 \mathrm{hPa}$. 
a

10868 Muenchen-Oberschlssheim

100

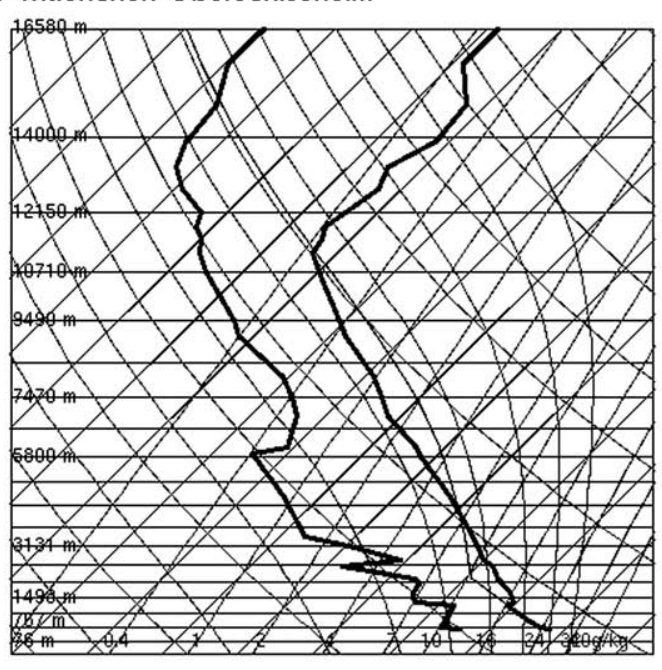

SLAT 48.25

SLON 11.55

SELV 489.0

SHOW 0.95

$\begin{array}{lll}\exists & \text { LIFT } & -2.90 \\ & \text { LFTV } & -3.45 \\ & \text { SWET } & 110.3 \\ & \text { KINX } & 19.50\end{array}$

$\exists \begin{array}{lll}\exists & \text { LFTV } & -3.45 \\ \Rightarrow & \text { SWET } & 110.3 \\ \text { KINX } & 19.50\end{array}$

$\exists \begin{array}{lll}\exists & \text { LFTV } & -3.45 \\ \Rightarrow & \text { SWET } & 110.3 \\ \text { KINX } & 19.50\end{array}$

200

CTOT 17.70

VTOT 30.70

TOTL 48.40

CAPE 845.0

CAPV 939.1

CINS -178 .

CINV -108 .

EQLV 229.9

EQTV 229.9

LFCT 622.4

LFCV 678.4

BRCH 36.26

BRCV 40.29

LCLT 283.7

LCLP 786.6

700

800

900

$\begin{array}{lllllllll}-40 & -30 & -20 & -10 & 0 & 10 & 20 & 30 & 40\end{array}$

MLMR 10.35

MLMR 10.35

$\begin{array}{ll}\text { THCK } & 5724 . \\ \text { PWAT } & 21.27\end{array}$

$12 Z 09$ Jul 2002

University of Wyoming

b

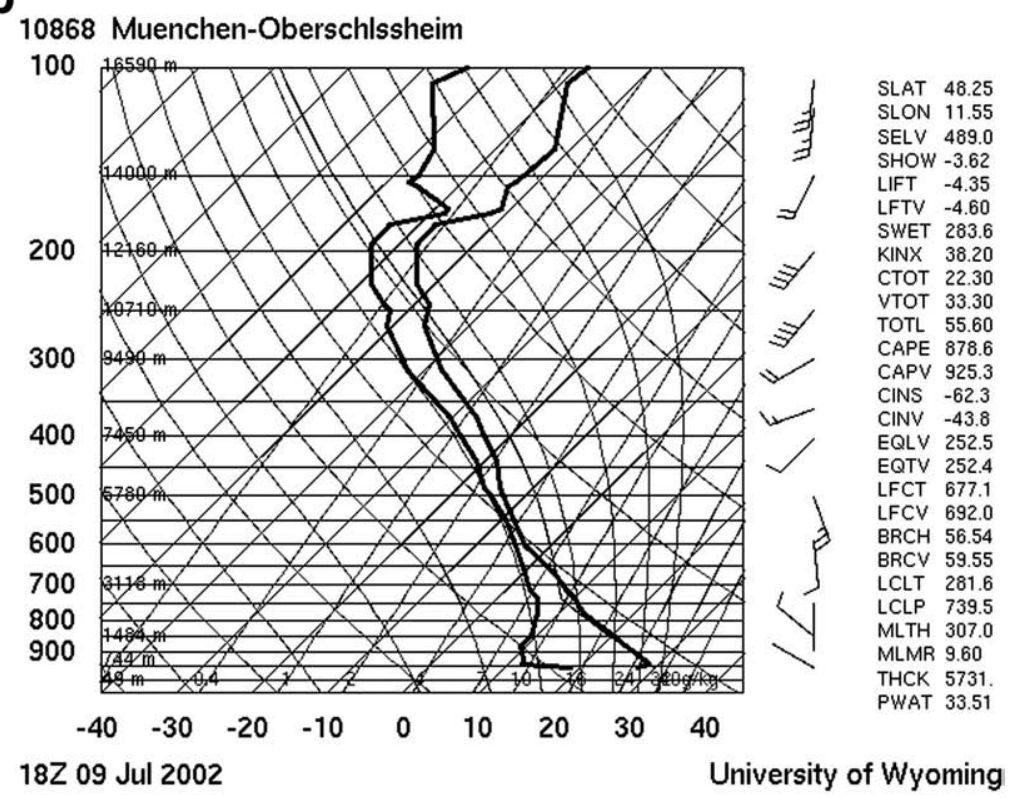

Fig. 7. Munich soundings of 9 July 2002, 1200 UTC (a) and 1800 UTC (b), courtesy of the University of Wyoming.

Simultaneously, the moisture decreases continuously towards the surface and leads to a wedge- or triangleshaped area between temperature and dewpoint curves in the skew- $T$, log- $p$ diagram. This is a necessary ingredient for development of vigorous downdrafts from thunderstorms. Besides, the directional shear had increased from 1200 to 1800 UTC, while CAPE was maintained at about $930 \mathrm{~J} \mathrm{~kg}^{-1}$. Consequently, thermodynamic conditions became more favourable for the development of F1-microbursts later in the day, which occurred for instance north of Augsburg (cf. Fig. 2) as the storms continued to propagate northeastwards away from the Alps.
Fig. 8 shows a vertical cross section (RHI) towards the southwest through the developing storms at 1536 UTC, when they had left the Alpine foothills and started to advance towards Munich. At this time, they were also within the field of view of the bistatic network, and reconstructed wind vectors were shown by Friedrich and Caumont (2004). This was also the likely breeding time for the downdrafts which later intensified to the downburst southwest of Munich. Fortunately, here also the RHI scans have the full set of polarimetric parameters available to verify the Atlas et al. (2004) findings. Aside from a hailspike signature in both panels of Fig. 8, the differential reflectivity in Fig. 8a at about 


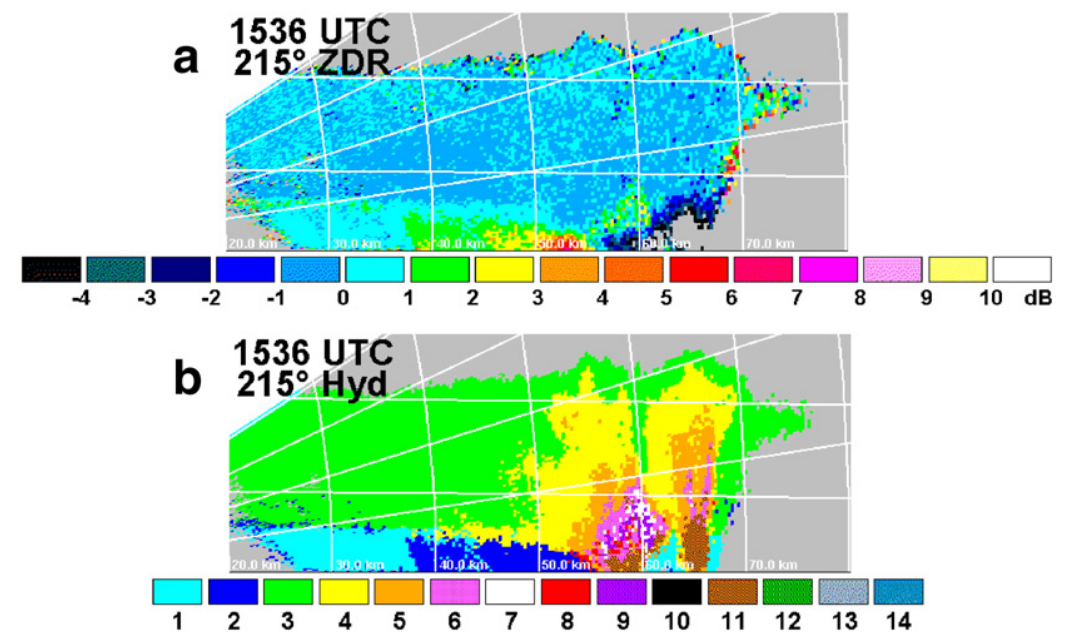

Fig. 8. Differential reflectivity ZDR (a) and hydrometeor classification (b, cf. Table 2) of RHI scans ( $215^{\circ}$ azimuth) at 1536 UTC on 9 July 2002 . In (a), a layer with enhanced ZDR values around or above $2 \mathrm{~dB}$ can be seen between 55 and $62 \mathrm{~km}$ range, and (b) reveals hydrometeor classes 4 and 6 to 9 in the same region, of which 6 and 8 are indicative of a region with melting or wet hail.

$60 \mathrm{~km}$ from the radar shows a curved layer of enhanced ZDR ( 2 to $3 \mathrm{~dB}$ ) at 2 to $4 \mathrm{~km}$ altitude. Its curvature is likely caused by the updraft of the thunderstorms, lifting both hydrometeors as well as the melting layer upward in its core. In the same region of enhanced ZDR, Fig. 8b indicates hydrometeor classes 6 to 9, among which classes 6 and 8 (i.e., wet hail or a mixture of rain and small wet hail) are candidate classes for the melting of small hail in progress. This is direct evidence in support of the Atlas et al. (2004) mechanism for downdraft initiation, then further enhanced by the thermodynamic stratification.

The downburst about $15 \mathrm{~km}$ southwest of Munich between 1730 and 1745 UTC is documented in Fig. 9. Serendipitous highquality photographs of the storm were taken towards the southwest (Fig. 9a) with POLDIRAD being located some $10 \mathrm{~km}$ to the right from the photographer's point of view (Fig. 9b). The wall cloud of the likely supercell thunderstorm in the foreground is formed from very moist surface air drawn into the updraft and leading to the lowering of the cloud base. A very dense and opaque precipitation core over the downburst area can be seen in the background. There, the largest hail and the wind damage in the forest were observed by storm chasers.

In the same time period, several vertical cross sections through this thunderstorm were made, of which the one shown in Fig. 9c intersects the storm roughly through its centre, see Fig. 9b. The reflectivity field is characterised by a strong hailspike signal again, and the reflectivity in the storm core generally lies between 50 and $60 \mathrm{dBZ}$. Contrary to Fig. 8, the ZDR field in these RHI scans could not be evaluated, similar to the situation on 21 June 2002. ZDR and consequently also the hydrometeor distribution are only available from the PPI scans made at this time. Hydrometeor identification of the $1^{\circ}$ PPI at 1734 UTC in Fig. 9d indicates a substantial amount of pixels with the hydrometeor classes 2 (large raindrops) or 8 and 9 (rain mixed with small or large hail, respectively, cf. Table 2). The core of the thunderstorm, corresponding to the $3 \mathrm{~cm}$ hail reports has a much smaller diameter, consistent with the 1736 UTC RHI in Fig. 9c. So the regions adjacent to the core might indeed have been dominated by small hail only, and the presence of a layer with enhanced ZDR as in Fig. 8a is at least not unlikely.

For 21 June and 9 July, also a comparison of BLIDS CG data to the total lightning and polarimetric radar analysis of Dotzek et al. (2001) or Fehr et al. (2005) in order to enhance nowcasting algorithms might be possible. Yet, in the present paper, the lightning and radar data synthesis is deferred, and instead, the operational predictability is studied in more detail in the following section.

\section{Predictability of wet downbursts}

While the previous sections dealt mainly with real-time radar detection of nowcasting indicators for the downburstproducing storms, the information contained in the atmospheric soundings has not been fully exploited yet. Table 1 reviews the basic parameters from the 1200 UTC soundings (1400 CEDT) on the VERTIKATOR days and for comparison from the 12 July 1984, the 21 July 1998 and 23 March 2001 cases (Dotzek et al., 2001, 2007) as well as the 10 July 2002 Berlin derecho (Gatzen, 2004). We will now evaluate the WINDEX and GUSTEX indices, designed for operational prediction of microburst likelihood, for all the days in Table 1 . Here, the fair weather day 8 July 2002 will serve as a null case to test if the indices capture the absence of damaging winds on this day.

According to McCann (1994), the Wind Index or WINDEX (in knots), short WI, can be computed from

$\mathrm{WI}=5\left[H_{\mathrm{m}} \max \left(r_{1} / 12,1\right)\left\{\Gamma^{2}-5.5^{2}+r_{1}-2 r_{\mathrm{m}}\right\}\right]^{1 / 2}$,

where $H_{\mathrm{m}}$ is the height of the melting layer in $\mathrm{km}$ AGL, $r_{1}$ is the average mixing ratio in the lowest $1 \mathrm{~km}$ AGL, $\Gamma$ denotes the bulk lapse rate in $\mathrm{K} \mathrm{km}^{-1}$ between the surface and the freezing level, and $r_{\mathrm{m}}$ is the mixing ratio at the melting level.

Eq. (1) is supported by theoretical arguments, but its design is highly empirical. It is based on the fact that downdrafts originate at about the melting level, and that their 


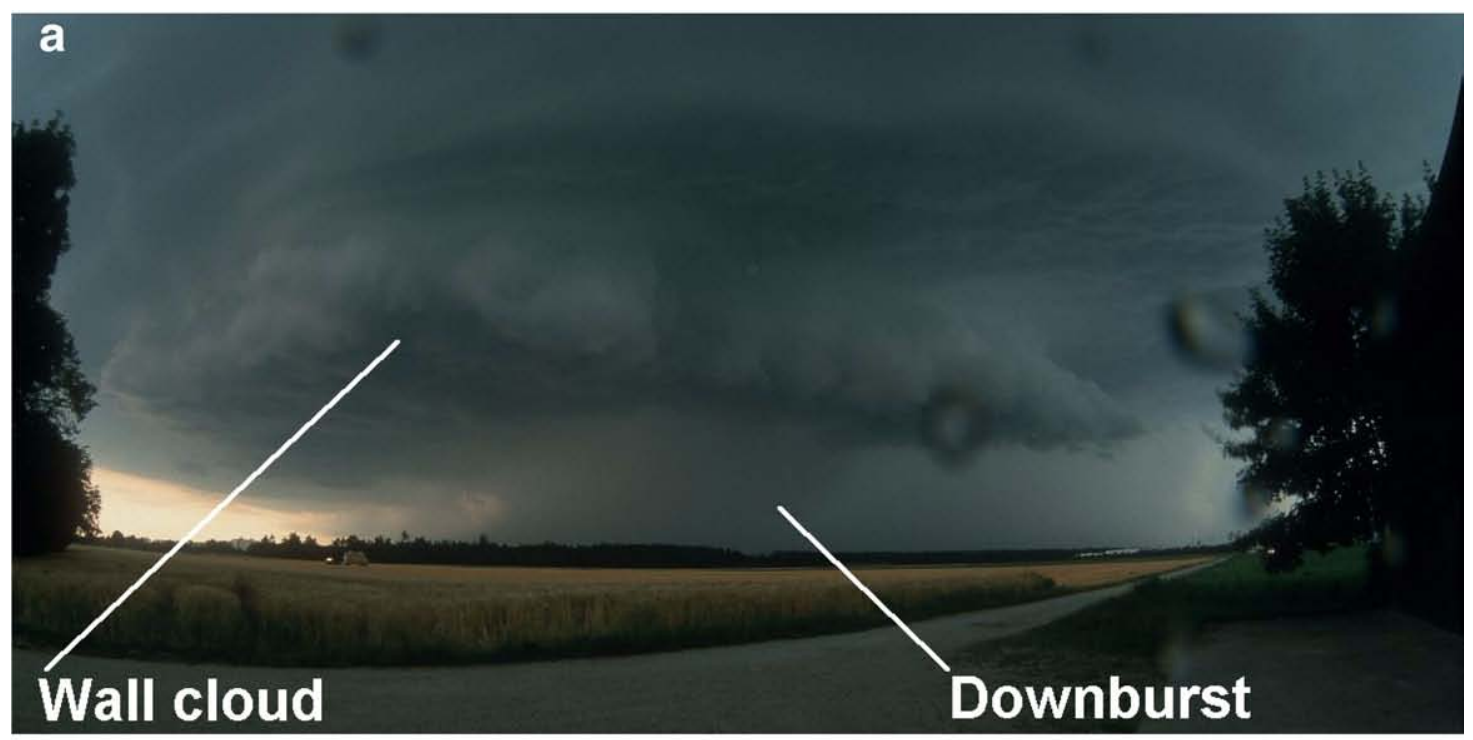

b

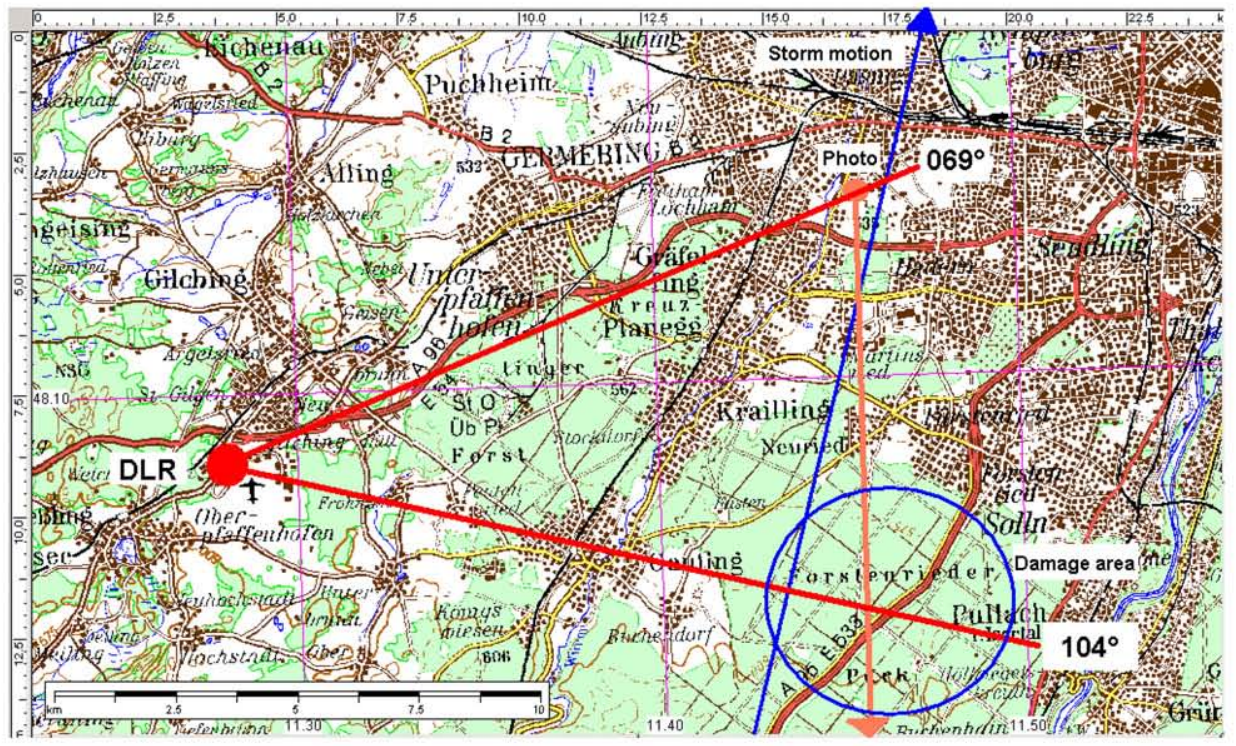

C
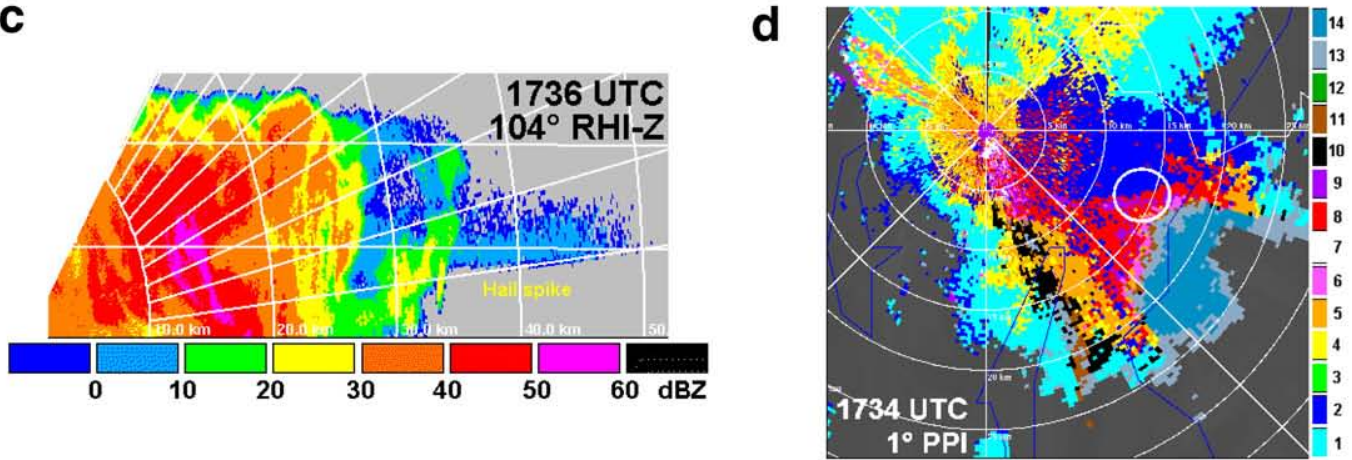

Fig. 9. The downburst southwest of Munich on 9 July 2002. (a) View from the north-northeast towards the approaching cell with wall cloud in front and precipitation core in the background (1735-1745 UTC, 16 mm fisheye lens, photo courtesy Rainer Timm). Panel (b) shows the damage area (blue circle) and the position of the photographer relative to the radar site. Panel (c) depicts an RHI of radar reflectivity through the same storm at 1736 UTC and $104^{\circ}$ azimuth (cf. panel b), showing a pronounced hailspike signature. Panel (d) gives the hydrometeor distribution in a $1^{\circ} \mathrm{PPI}$ at $1734 \mathrm{UTC}$. The white circle replicates the damage area from (b). 
kinetic energy is proportional to the depth of the descent and the square of the lapse rate over this depth and exceeding a certain threshold (Srivastava, 1985, 1987). McCann (1994) motivated the use of an average of $r_{1}$ over the lowest kilometre AGL with the argument that $r_{1}$ is a more robust and representative quantity compared to taking the mixing ratio at a single level only, like at $1 \mathrm{~km}$ AGL as a proxy of moisture at the top of the boundary layer. To compute $r_{1}$, first specific humidity $q$ being the relevant conservative quantity is derived from

$q=r /(1+r)$.

After computing $\rho$ from the ideal gas law, the low-level specific humidity $q_{1}$ follows from

$q_{1}=\frac{\int_{0}^{z=1 \mathrm{~km} \mathrm{AGL}} \rho q \mathrm{~d} z}{\int_{0}^{z=1 \mathrm{~km} \mathrm{AGL}} \rho \mathrm{d} z}$,

and can be used to derive $r_{1}$ from an inversion of Eq. (2). Note that depending on the actual lapse rate, the radicand in Eq. (1) may become negative. In these cases, WI is held fixed at zero, as it smoothly approaches zero for smaller and smaller values of $\Gamma$

Two alternative methods exist to derive WI from a given sounding, depending on two ways $\Gamma_{1}$ and $\Gamma_{2}$ to compute the bulk lapse rate (cf. Geerts, 2001):

1. $\mathrm{WI}_{1}$ uses the raw sounding temperatures at the surface and the freezing layer, that is, $\Gamma_{1}=\left(T_{\mathrm{m}}-T_{\mathrm{s}}\right) / \mathrm{H}_{\mathrm{m}}$;

2. $\mathrm{WI}_{2}$ incorporates an estimate (or a posteriori data) of the actual maximum surface temperatures before the high wind event: $\Gamma_{2}=\left(T_{\mathrm{m}}-T_{\mathrm{s}, \max }\right) / H_{\mathrm{m}}$.

This alternative is also being evaluated in the present paper: $\mathrm{WI}_{1}$ is computed from any sounding, and additionally, $\mathrm{WI}_{2}$ is derived for all 1200 UTC soundings using the observed afternoon maximum temperatures in the region of interest. For all other soundings, $\mathrm{WI}_{2}=\mathrm{WI}_{1}$.

Geerts (2001) added another term to WINDEX to incorporate the influence of vertical momentum transport from higher levels as a factor contributing to high wind events at the ground. From the assumption of ideal momentum conservation, he arrived at the gust index (GUSTEX, or short GU):

$\mathrm{GU}_{n}=\alpha \mathrm{WI}_{n}+\frac{\rho_{500}}{\rho_{\mathrm{s}}} U_{500}$.

Here, $\rho_{500}$ is the air density at the $500 \mathrm{hPa}$ level and $\rho_{\mathrm{s}}$ is the air density at the surface. $U_{500}$ is the wind (in knots) at the 500 hPa level, and $\alpha$ is an empirical constant $(0<\alpha<1)$ to tune GUSTEX to observed high winds at the surface. The index $n$ in Eq. (4) distinguishes the alternatives in WINDEX computation from the distinction between $\Gamma_{1}$ and $\Gamma_{2}$ in Eq. (1). From his data, Geerts (2001) selected $\alpha=0.6$ and replaced $\rho_{500} / \rho_{\text {s }}$ by its approximate value 0.5 . In the present paper, the term $\rho_{500} /$ $\rho_{\mathrm{s}}$ is retained, and $\alpha=0.6$ is only used for consistency with Geerts (2001) in $\mathrm{GU}_{1}$ and $\mathrm{GU}_{2}$.

Geerts (2001) had made an aside that instead of using the momentum at the $500 \mathrm{hPa}$-level in Eq. (4), "perhaps a densityweighted mean wind between the 1 and $5 \mathrm{~km}$ AGL levels would have been a better choice" - in other words, the average momentum confined between these two levels. We confirm that this should indeed be a better choice, in line with the reasoning mentioned above concerning the choice of $r_{1}$ : If vertical advection of high momentum aloft is to be represented in a forecast index, then an average over the depth of the layer likely contributing to the downdraft is preferable compared to any arbitrarily chosen single mid-tropospheric level.

Thus, we introduce the density-weighted mean wind $\langle U\rangle$ (in knots) analogous to Eq. (3)

$\langle U\rangle=\frac{\int_{z=1 \mathrm{~km} \mathrm{AGL}}^{z=5 \mathrm{~km} \mathrm{AGL}} \rho U \mathrm{~d} z}{\int_{z=1 \mathrm{~km} \mathrm{AGL}}^{z=5 \mathrm{~km} \mathrm{AGL}} \rho \mathrm{d} z}$

Simultaneously, we omit the tuning parameter $\alpha$ of Eq. (4), to arrive at a new formulation of GUSTEX as a pure superposition of two terms, measuring (i) the downburst potential from the atmospheric stratification and (ii) the potential that high winds from aloft are brought to the surface:

$\mathrm{GU}_{n+2}=\mathrm{WI}_{n}+\langle U\rangle$.

This yields GUSTEX parameters $\mathrm{GU}_{3}$ and $\mathrm{GU}_{4}$, for which the alternative again follows from the two ways to compute WI with different choices of $\Gamma$. Accordingly, $\mathrm{GU}_{2}$ and $\mathrm{GU}_{4}$ only attain individual values for the 1200 UTC soundings. Otherwise, they are equal to $\mathrm{GU}_{1}$ and $\mathrm{GU}_{3}$, respectively.

In contrast to the studies for Texas and adjacent states in the USA by McCann (1994) and for New South Wales, Australia by Geerts (2001), in Central Europe usually the 1200 UTC soundings will be the most relevant to probe the preconvection airmass, and they will also be available from all stations. Soundings at 1800 or even 1500 UTC might also serve as adequate proximity soundings (Brooks et al., 1994), but these will usually not be available routinely. To derive the data in Table 3, we have used the 1200 UTC soundings, but also evaluated all other soundings during the days with severe weather. In most cases, these were the 0000 UTC soundings, but occasionally also 0600 or 1800 UTC radiosondes, especially during the VERTIKATOR IOP from 8 to 10 July 2002.

To augment the database for our study, we have added 8 July 2002, a fair-weather day, to the VERTIKATOR cases discussed in Section 3, as well as some more severe weather cases that had been studied earlier on, for instance, the Munich hailstorm of 12 July 1984, the EULINOX supercell of 21 July 1998 (Dotzek et al., 2001; Fehr et al., 2005), and the 23 March 2001 downbursts (Dotzek et al., 2007). On 10 July 2002, southern Germany was affected by a squall line at about 1200 UTC, but the most severe event initiated only after 1430 UTC: A long line of thunderstorms formed from northern Germany to the Czech Republic and developed into a derecho hitting Berlin in the evening (Gatzen, 2004). To test WINDEX and GUSTEX for this airmass as well, we added the 1200 UTC sounding from Prague, Czech Republic, and the 1800 UTC sounding from Lindenberg located about $40 \mathrm{~km}$ southeast of Berlin.

The indices from Eqs. (1), (4) and (6) were computed for all these cases and compared to the observed convective wind gusts or corresponding wind damage (Table 3). The two WI and four GU parameters are also shown for all 29 investigated soundings in Table 3, where the indices have been converted 
Table 3

Observed daily peak gust speed ranges ( $F$-scale), and $\mathrm{WI}_{n}$ and $\mathrm{GU}_{n}$ in $\mathrm{m} \mathrm{s}^{-1}$ from Munich (10868) and Stuttgart (10739) soundings. For 10 July 2002 (Berlin derecho), soundings from Prague (11520) and Lindenberg (10393) are also shown. To obtain $\mathrm{WI}_{n}$ and $\mathrm{GU}_{n}$ values (cf. Eqs. (4) and (6)) in knots, multiply our numbers by two. As in Table 1, 8 July 2002 (a clear summer day with dry convection) serves as a null case here.

\begin{tabular}{|c|c|c|c|c|c|c|c|c|}
\hline \multirow{2}{*}{$\begin{array}{l}\text { Date, UTC } \\
\text { yymmdd, hh }\end{array}$} & \multirow{2}{*}{$\begin{array}{l}\text { WMO } \\
\text { station }\end{array}$} & \multirow{2}{*}{$\frac{\text { Obs. }}{\text { F-scale }}$} & \multirow{2}{*}{$\frac{\mathrm{WI}_{1}}{\mathrm{~m} \mathrm{~s}^{-1}}$} & \multirow{2}{*}{$\frac{\mathrm{WI}_{2}}{\mathrm{~m} \mathrm{~s}^{-1}}$} & \multirow{2}{*}{$\frac{\mathrm{GU}_{1}}{\mathrm{~m} \mathrm{~s}^{-1}}$} & \multirow{2}{*}{$\frac{\mathrm{GU}_{2}}{\mathrm{~m} \mathrm{~s}^{-1}}$} & \multirow{2}{*}{$\frac{\mathrm{GU}_{3}}{\mathrm{~m} \mathrm{~s}^{-1}}$} & \multirow{2}{*}{$\frac{\mathrm{GU}_{4}}{\mathrm{~m} \mathrm{~s}^{-1}}$} \\
\hline & & & & & & & & \\
\hline 40712,00 & 10868 & & 3.65 & $\mathrm{WI}_{1}$ & 13.81 & $\mathrm{GU}_{1}$ & 18.44 & $\mathrm{GU}_{3}$ \\
\hline 840712,12 & 10868 & $\mathrm{~F} 1$ & 23.16 & 28.12 & 28.11 & 31.09 & 37.38 & 42.34 \\
\hline 840713,00 & 10868 & & 0.00 & $\mathrm{WI}_{1}$ & 10.91 & $\mathrm{GU}_{1}$ & 21.34 & $\mathrm{GU}_{3}$ \\
\hline 980721,00 & 10868 & & 0.00 & $\mathrm{WI}_{1}$ & 3.99 & $\mathrm{GU}_{1}$ & 4.42 & $\mathrm{GU}_{3}$ \\
\hline 980721,12 & 10868 & $\mathrm{~F} 0, \mathrm{~F} 1(?)$ & 30.39 & 35.87 & 24.73 & 28.02 & 39.35 & 44.83 \\
\hline 980722,00 & 10868 & & 0.00 & $\mathrm{WI}_{1}$ & 5.22 & $\mathrm{GU}_{1}$ & 8.66 & $\mathrm{GU}_{3}$ \\
\hline 010323, 12 & 10739 & F0 & 0.00 & 4.56 & 12.91 & 15.64 & 28.70 & 33.26 \\
\hline 010323,18 & 10739 & $\mathrm{n} / \mathrm{a}$ & 13.25 & $\mathrm{WI}_{1}$ & 59 & $\mathrm{GU}_{1}$ & 42.52 & $\mathrm{GU}_{3}$ \\
\hline 10324,00 & 10739 & $\mathrm{n} / \mathrm{a}$ & 6.98 & $\mathrm{WI}_{1}$ & 22.15 & $\mathrm{GU}_{1}$ & 31.43 & $\mathrm{GU}_{3}$ \\
\hline 10323,12 & 10868 & $\mathrm{~F} 1, \mathrm{~F} 2$ & 0.00 & 9.88 & 14.58 & 20.51 & 29.01 & 38.89 \\
\hline 010324,00 & 10868 & $\mathrm{n} / \mathrm{a}$ & 0.00 & $\mathrm{WI}_{1}$ & 16.84 & $\mathrm{GU}_{1}$ & 25.64 & $\mathrm{GU}_{3}$ \\
\hline 020620, 00 & 10868 & & 0.00 & $\mathrm{WI}_{1}$ & 5.71 & $\mathrm{GU}_{1}$ & 7.31 & $\mathrm{GU}_{3}$ \\
\hline 020620, 12 & 10868 & F0 & 24.97 & 28.39 & 20.87 & 22.92 & 35.15 & 38.58 \\
\hline 020621, 00 & 10868 & & 0.00 & $\mathrm{WI}_{1}$ & 4.22 & $\mathrm{GU}_{1}$ & 8.55 & $\mathrm{GU}_{3}$ \\
\hline 020621, 12 & 10868 & $\mathrm{~F} 1$ & 25.21 & 32.64 & 22.06 & 26.52 & 34.86 & 42.29 \\
\hline 020622, 00 & 10868 & & 0.00 & $\mathrm{WI}_{1}$ & 10.04 & $\mathrm{GU}_{1}$ & 13.39 & $\mathrm{GU}_{3}$ \\
\hline 00 & 10868 & & 0.00 & $\mathrm{WI}_{1}$ & 6.05 & $\mathrm{GU}_{1}$ & .76 & $\mathrm{GU}_{3}$ \\
\hline 020708, 06 & 10868 & & 0.00 & $\mathrm{WI}_{1}$ & 4.58 & $\mathrm{GU}_{1}$ & 7.86 & $\mathrm{GU}_{3}$ \\
\hline 020708, 12 & 10868 & Dry & 19.27 & 27.18 & 13.59 & 18.33 & 25.52 & 33.42 \\
\hline 020708, 18 & 10868 & Dry & 23.35 & $\mathrm{WI}_{1}$ & 18.35 & $\mathrm{GU}_{1}$ & 29.90 & $\mathrm{GU}_{3}$ \\
\hline 020709, 00 & 10868 & & 0.00 & $\mathrm{WI}_{1}$ & 3.95 & $\mathrm{GU}_{1}$ & 5.79 & $\mathrm{GU}_{3}$ \\
\hline 020709, 06 & 10868 & & 0.00 & $\mathrm{WI}_{1}$ & 5.18 & $\mathrm{GU}_{1}$ & 5.89 & $\mathrm{GU}_{3}$ \\
\hline 020709, 12 & 10868 & $\mathrm{~F} 1$ & 26.02 & 34.12 & 22.11 & 26.97 & 32.88 & 40.99 \\
\hline 020709, 18 & 10868 & $\mathrm{~F} 1$ & 23.66 & $\mathrm{WI}_{1}$ & 20.20 & $\mathrm{GU}_{1}$ & 28.78 & $\mathrm{GU}_{3}$ \\
\hline 020710,00 & 10868 & & 0.00 & $\mathrm{WI}_{1}$ & 5.26 & $\mathrm{GU}_{1}$ & 8.06 & $\mathrm{GU}_{3}$ \\
\hline 020710,12 & 10868 & F0 & 21.80 & 31.33 & 22.09 & 27.81 & 31.57 & 41.10 \\
\hline 020711, 00 & 10868 & & 0.00 & $\mathrm{WI}_{1}$ & 9.54 & $\mathrm{GU}_{1}$ & 10.48 & $\mathrm{GU}_{3}$ \\
\hline 020710, 12 & 11520 & F0 & 30.09 & 33.02 & 24.92 & 26.67 & 39.18 & 42.10 \\
\hline 020710, 18 & 10393 & $\mathrm{~F} 1, \mathrm{~F} 2$ & 31.45 & $\mathrm{WI}_{1}$ & 27.14 & $\mathrm{GU}_{1}$ & 42.78 & $\mathrm{GU}_{3}$ \\
\hline
\end{tabular}

from knots to $\mathrm{m} \mathrm{s}^{-1}$ for convenience. Note that the internationally most widely-used threshold for damaging straightline winds is $25 \mathrm{~m} \mathrm{~s}^{-1}$, so cases in which $\mathrm{WI}_{n}$ or $\mathrm{GU}_{n}$ remain below his threshold will not be counted as severe.

Table 3 shows that the indices perform surprisingly well in most cases. Starting with the $\mathrm{WI}_{n}$ indices (with $\mathrm{WI}_{2}$ only differing from $\mathrm{WI}_{1}$ for the $1200 \mathrm{UTC}$ soundings), values close to or even above the $25 \mathrm{~m} \mathrm{~s}^{-1}$ threshold occur only if severe weather was indeed impending, except for two cases: On 23 March 2001, the downburst potential was underestimated. On this day, the high mid-tropospheric winds played a major role, but they are not captured by the WI index. On 8 July 2002, winds slightly below or above the $25 \mathrm{~m} \mathrm{~s}^{-1}$ threshold were predicted by WI, despite the absence of any significant weather. At first glance, one might speculate that the thermodynamic stratification may already have displayed some characteristics of the severe weather period during the following days, with WI having responded to these. If so, 8 July would not be a true, independent null case.

However, a more likely explanation follows from comparison of Eq. (1) and the Munich soundings of 8 July, 1200 and 1800 UTC: WI was dominated by a large altitude of the melting layer close to the $600 \mathrm{hPa}$ level (but with a relatively low LCL at about $770 \mathrm{hPa}$ ) as well as dry air and a nearly moist adiabatic lapse rate throughout most of the troposphere. Thus any moist downdrafts originating from the melting layer region would have experienced nearly uninhibited downward acceleration on their way to the ground. In fact, this might have been a day on which to expect dry downbursts, had there only been any saturated downdrafts starting farther aloft.

So in principle, WINDEX performed rather well in diagnosing the dry downburst potential on this particular day, but as there were no high-level moist downdrafts, any air masses going down warmed dry-adiabatically and were quickly decelerated after becoming warmer than the environment. Given the relatively weak flow below $5 \mathrm{~km} \mathrm{AGL,} \mathrm{it} \mathrm{is}$ reassuring that extending WINDEX to GUSTEX by adding the influence of the airflow aloft does not increase the values for 8 July further, but lowers them at least for $\mathrm{GU}_{1}$ and $\mathrm{GU}_{2}$ below the $25 \mathrm{~m} \mathrm{~s}^{-1}$ threshold.

In general, Geerts (2001) original GUSTEX formulation, $\mathrm{GU}_{1}$ (and $\mathrm{GU}_{2}$ for the 1200 UTC soundings) are usually higher than the corresponding $\mathrm{WI}_{n}$ values for the soundings in situations without (or prior to) deep moist convection, but they always remain below the $25 \mathrm{~m} \mathrm{~s}^{-1}$ threshold. For 23 March 2001, the $\mathrm{GU}_{n}$ perform much better than the $\mathrm{WI}_{n}$, based on a comparison with the F-scale ratings of the events on that day. Yet for the other soundings preceding severe weather, the GU values are often lower than the original WI index. This result came unexpected and was not noted by Geerts (2001) for his Australian cases.

The reason for this effect is obvious: The choice of $\alpha=0.6$ in Eq. (4) downgrades the thermodynamic potential for downbursts, so that quite strong winds at the $500 \mathrm{hPa}-$ level would have to be present to compensate or even to outweigh this low emphasis placed on WI in Eq. (4). While $\alpha=0.6$ may have been a good choice for the Australian downbursts of Geerts (2001), it is apparently not a good choice for our cases. In general, tuning parameters like $\alpha$ which may depend on the regional downburst climatology (or even the dataset of events used to "train" the forecast index) complicate or even prevent its general applicability.

Certainly, good aspects of our new formulation of GUSTEX according to Eq. (6) are that there is no tuning parameter $\alpha$ any more and that the dynamical term captures the mean momentum between 1 and $5 \mathrm{~km}$ AGL, not just the $500 \mathrm{hPa}$ level as in the original GUSTEX formulation. For our database of events, the new $\mathrm{GU}_{3}$ (and $\mathrm{GU}_{4}$ at $1200 \mathrm{UTC}$ ) yields the highest forecast wind speeds. Now even a few of the 0000 UTC (but none from 0600 UTC) produce substantial index values, however, these normally remain below the $25 \mathrm{~m} \mathrm{~s}^{-1}$ threshold, except for the case 23 March 2001 which had unusually strong mid-tropospheric winds. But from a comparison to the WI values at these times, it can readily be seen that the thermodynamic potential for downburst is minimal.

For the remaining 1200 and 1800 UTC cases, $\mathrm{GU}_{3}$ and $\mathrm{GU}_{4}$ still yield the highest wind speeds. While the prediction of high wind gusts is correct for all these cases, the question is if the predicted wind speeds are realistic or even exaggerate what was actually observed later on. Here, we have to conclude that the forecast wind gusts are indeed close to the observations. Looking at the most significant events, we find about $42 \mathrm{~m} \mathrm{~s}^{-1}$ (upper half of F1) for the Munich hailstorm, in line with the observed damage at the time. The EULINOX day 21 July 1998 yielded GUSTEX values of 40 to $45 \mathrm{~m} \mathrm{~s}^{-1}$. The available TorDACH reports do not confirm these high intensities, but the storm reports from even the late $1990 \mathrm{~s}$ were not yet dense enough (cf. Fig. 1a) that we could claim with 
confidence that gusts of about $40 \mathrm{~m} \mathrm{~s}^{-1}$ did not occur on this day in the Munich region. For 23 March 2001, both Stuttgart and Munich soundings produce $\mathrm{GU}_{3}$ and $\mathrm{GU}_{4}$ values at or above $40 \mathrm{~m} \mathrm{~s}^{-1}$. As shown by Dotzek et al. (2007), one of the downbursts close to Munich on that day was even rated F2 based on the observed forest damage. The lower threshold of F2 on the Fujita scale is at $50.4 \mathrm{~m} \mathrm{~s}^{-1}$ (cf. Dotzek et al., 2005), so the GU values still appear to be on the conservative side.

In the VERTIKATOR cases of June and July 2002, the GU values group around the lower F1 threshold ( $33 \mathrm{~m} \mathrm{~s}^{-1}$ ), with some peak values above $40 \mathrm{~m} \mathrm{~s}^{-1}$, also in line with the observed damage. While we only have F0 observations on 20 June 2002, we can again not completely rule out the presence of local gusts around the F1 threshold. For the airmass of the Berlin derecho, the predicted gusts are consistently above $42 \mathrm{~m} \mathrm{~s}^{-1}$ - also no over-prediction given the F1 and F2 damage which occurred in and around Berlin in the evening.

\section{Discussion}

The major focal points of this work were to investigate

1. if (thermo-)dynamic setups for downbursts similar to those in the USA exist in Europe;

2. which processes likely lead to the initial downdraft formation and later intensification;

3. if aside from radar nowcasting also operationally useable forecast parameters exist to estimate the downburst potential on days when thunderstorms are forecast.

Our study provided answers for all three points, albeit based on a preliminary sample of cases. The first point was easiest to clarify. Wet downbursts are quite common events, and their environments in Europe do not appear to differ substantially from those in the USA or elsewhere in the world. While dry microburst environments seem to be rare in Europe due to the absence of very deep ( 2 to $4 \mathrm{~km}$ ) dry-adiabatic planetary boundary layers in most regions (except probably in central Spain - see the 7 July 2007, 1200 UTC Madrid sounding), we found evidence that even the Munich sounding on 8 July 2002 had some dry downburst potential which, however, did not materialise due to the lack of high-based clouds.

The second point concerning the trigger mechanism for the initial downdraft formation is more difficult to clarify. The direct hydrometeor drag by large hailstones seems to be of secondary importance at best, as on all three days investigated, large hail was limited to a small portion of the thunderstorm volume. Evaporation of rain has certainly contributed to the intensification of the downdrafts below cloud base, but is unlikely to have played a major role in forming the initial drafts, as the airflow towards the ground has apparently originated higher up, above cloud base, where also the environmental air showed small spreads between temperature and dewpoint. So we have some confidence that the melting of smaller frozen hydrometeors was the most likely candidate process for downdraft initiation in our cases.

To become intense, downbursts should originate at or above well-mixed layers with steep lapse rates, in order to have the whole depth of the mixed layer for acceleration towards the ground. Such layers existed on all three VERTIKATOR days studied here, and their top level was at about the freezing level, where also the highest relative humidity was found, approach- ing saturation on 21 June and 9 July. Under these ambient conditions, evaporation is an inefficient process. Melting, however, is increasingly effective for higher relative humidity, as also stressed by Atlas et al. (2004).

These circumstances, complemented by the POLDIRAD radar measurements presented here, support the conclusion that the melting of ice particles like smaller hailstones or graupel plays an important role in wet downburst formation in Central Europe as well. While this conclusion needs further confirmation from a larger set of studied cases, we may stress the importance to exploit the capabilities of modern polarimetric radar to detect in-cloud regions with melting hail or graupel and to use it in nowcasting algorithms to warn of an imminent downburst threat.

As shown above, especially the new $\mathrm{GU}_{3}$ and $\mathrm{GU}_{4}$ indices performed rather well, at least for the still relatively small sample of events analysed here. In general, applicability of WINDEX or GUSTEX depends on the timing of available proximity radiosonde relative to the start of severe convective storms, as well as on the local climatology of microbursts.

The indices $\mathrm{GU}_{3}$ and $\mathrm{GU}_{4}$ using the 1200 or 1800 UTC soundings seem to be the most suitable for representing the downburst probability for the studied cases. At other times of the day, for example during the night, $\mathrm{GU}_{3}$ and $\mathrm{GU}_{4}$ may also yield high values when the setup is conducive for downburstproducing storms, but when the convective initiation is missing, for instance, due to lack of solar heating. In such cases, a parallel inspection of WI can identify these cases which only lead to high $\mathrm{GU}_{3}$ and $\mathrm{GU}_{4}$ values because of strong mid-tropospheric flow. And apparently, real attention to the indices should only be paid if the $\mathrm{GU}_{3}$ and $\mathrm{GU}_{4}$ values exceed $25 \mathrm{~m} \mathrm{~s}^{-1}$.

Contrary to what Geerts (2001) reported, his $\mathrm{GU}_{1}$ and $\mathrm{GU}_{2}$ can sometimes lead to a degradation of the basic WI values. This is generally not a desired feature and can lead to quite significant under-predictions, as shown in Table 3 on 21 July 1998 , and for nearly all of the cases in the VERTIKATOR period. Nevertheless, a larger sample of events is needed to quantify this potential under-prediction further, as well as to corroborate the encouraging performance of $\mathrm{GU}_{3}$ and $\mathrm{GU}_{4}$.

\section{Conclusions}

In addition to the recent analysis of two downbursts in the same area of southern Germany in the cold season (Dotzek et al., 2007), also warm season, orographically forced thunderstorms moving into the Alpine foreland have repeatedly shown considerable downburst potential. For these, we conclude that

- The melting of smaller hail or graupel appears as the best candidate for cooling air near the melting layer to make it negatively buoyant. During its descent below cloud base, also evaporation of rain may become significant in accelerating the downdraft to downburst intensity. There is no evidence that hydrometeor drag of large hail may have triggered the downdrafts;

- Thermodynamic soundings with deep, steep lapse rate layers, supporting wet or even dry microbursts do exist in Europe. Over the Alpine foreland, the nearby Alps likely have assisted in creating these soundings by superposing an 
elevated mixed layer atop the convective boundary layer. In this case, nearly the whole layer below the freezing level may become close to dry-adiabatic;

- Our study presented the first wind vector fields in a downburst measured by a bistatic C-band polarimetric radar network. The bistatic radar was much better suited to detect downburst structure and intensity than POLDIRAD alone;

- As bistatic networks will remain the exception, the upcoming operational polarimetric surveillance radar generation should be equipped with optimised nowcasting algorithms allowing automatic detection of layers with melting small hail for early warning of potential downburst initiation or detection of developing intense downdrafts;

- The WINDEX and GUSTEX indices performed well for the wet downburst cases analysed here. This holds in particular for our modified formulation of GUSTEX, that is $\mathrm{GU}_{3}$ or $\mathrm{GU}_{4}$. Future work based on a much larger sample of soundings will help to quantify this result in terms of skill scores;

- The skill can be assessed for two applications of WINDEX and GUSTEX: Either to only diagnose if damaging wind gusts might occur at all, or to also predict their intensity. Given the limited chance to adequately sample the maximum gusts on a given day from wind measurements or severe storm reports, we argue that using WI and GU merely to distinguish between damaging downburst days and non-severe days might show a higher skill;

- A procedure to apply $\mathrm{GU}_{3}$ or $\mathrm{GU}_{4}$ in central Europe in operational mode would be to evaluate the parameters from the 0000 and 1200 UTC soundings. If $\mathrm{GU}_{3}$ or $\mathrm{GU}_{4}$ exceed the threshold of $25 \mathrm{~m} \mathrm{~s}^{-1}$, a cross-check with WI should be performed. If also $\mathrm{WI}_{1}$ or $\mathrm{WI}_{2}$ exceed or are at least close to $25 \mathrm{~m} \mathrm{~s}^{-1}$, the potential for downbursts of the predicted intensity is large. However, if $\mathrm{WI}_{1}$ or $\mathrm{WI}_{2}$ are small or even zero, the downburst potential is still low.

The shown applicability of the WINDEX and GUSTEX indices need further verification from a larger set of operational experience over Europe. This is the topic of ongoing work.

\section{Acknowledgements}

The authors are grateful to Stefan Thern from Siemens AG for providing the BLIDS lightning data. The TorDACH storm reports and their climatological analysis can be accessed at www.tordach.org/de/ and are also contained at www.essl. org/ESWD/. Rainer Timm kindly provided his photos of the 9 July downburst, and additional storm chaser reports are available at www.sturmwetter.de. The University of Wyoming radiosonde archive proved to be highly useful for our analyses over the last years and is greatly acknowledged. Our referees provided thoughtful suggestions to improve the manuscript. This work was partly funded by the German Ministry for Education and Research BMBF under contracts 07ATF45 and 01LS05125 in the projects VERTIKATOR (Vertikaler Austausch und Orographie, Vertical transport and orography) and RegioExAKT (Regionales Risiko konvektiver Extremwetterereignisse: Anwenderorientierte Konzepte zur Trendbewertung und -anpassung, Regional risk of convective extreme weather events: User-oriented concepts for trend assessment and adaptation), as well as an Office of Naval Research, VSP travel grant No. N00014-03-1-4104.

\section{References}

Atlas, D., Williams, C.R., 2003. The anatomy of a continental tropical convective storm. J. Atmos. Sci. 60, 3-15.

Atlas, D., Ulbrich, C.W., Williams, C.R., 2003. Physical origin of a microburst seen by radar profiler. Preprints, 31st Conf. on Radar Meteor., Seattle, 6-12 August 2003. Amer. Meteor. Soc., Boston, pp. 551-554.

Atlas, D., Ulbrich, C.W., Williams, C.R., 2004. Physical origin of a wet microburst: observations and theory. J. Atmos. Sci. 61, 1186-1196.

Bech, J., Pascual, R., Rigo, T., Pineda, N., López, J.M., Arús, J., Gayà, M., 2007. An observational study of the 7 September 2005 Barcelona tornado outbreak. Nat. Hazards Earth Syst. Sci. 7, 129-139.

Bissolli, P., Grieser, J., Dotzek, N., Welsch, M., 2007. Tornadoes in Germany 1950-2003 and their relation to particular weather conditions. Glob. Planet. Change 57, 124-138.

Brooks, H.E., Doswell, C.A., 2001. Some aspects of the international climatology of tornadoes by damage classification. Atmos. Res. 56, 191-201.

Brooks, H.E., Doswell, C.A., Cooper, J., 1994. On the environments of tornadic and nontornadic mesocyclones. Wea. Forecasting 9 (4), 606-618.

Brooks, H.E., Lee, J.W., Craven, J.P., 2003. The spatial distribution of severe thunderstorm and tornado environments from global reanalysis data. Atmos. Res. 67-68, 73-94.

Brooks, H.E., Anderson, A.R., Riemann, K., Ebbers, I., Flachs, H., 2007. Climatological aspects of convective parameters from the NCAR/NCEP reanalysis. Atmos Res. 83, 294-305.

Cotton, W.R., Anthes, R.A., 1989. Storm and Cloud Dynamics. Int. Geophys. Ser., vol. 44. Academic Press, San Diego. 883pp.

Cummins, K.L., Murphy, M.J., Bardo, E.A., Hiscox, W.L., Pyle, R.B., 1998. A combined TOA/MDF technology upgrade of the U.S. National Lightning Detection Network. J. Geophys. Res. 103D, 9035-9044.

Dessens, J., Blin, P., 1988. Coups de vent de grain et trombes: Étude comparative sur deux cas récents (Downbursts and tornadoes: comparative study of two recent cases). La Météorologie 7, 4-18 [In French].

Dessens, J., Sanchez, J.L. (Eds.), 2007. Special Issue: European Conference on Severe Storms 2004. Atmos. Res., 83(2-4), pp. 119-560.

Doswell, C.A., 1993. Extreme convective windstorms: current understanding and research. Proceedings, Spain-U.S. Joint Workshop on Natural Hazards, Barcelona, 8-11 June 1993. 11 pp.

Doswell, C.A. (Ed.), 2001. Severe Convective Storms. Meteor. Monogr., vol. 28. Amer. Meteor. Soc., Boston. 561 pp.

Dotzek, N., 2001. Tornadoes in Germany. Atmos. Res. 56, 233-252.

Dotzek, N., 2003. An updated estimate of tornado occurrence in Europe. Atmos. Res. 67-68, 153-161.

Dotzek, N., Friedrich, K., 2003. Analysis of downburst-producing thunderstorms during the VERTIKATOR field experiment in southern Germany. Preprints, 31st Conf. on Radar Meteor., Seattle, 6-12 August 2003. Amer. Meteor. Soc., Boston, pp. 78-79.

Dotzek, N., Berz, G., Rauch, E., Peterson, R.E., 2000. Die Bedeutung von Johannes P. Letzmanns "Richtlinien zur Erforschung von Tromben, Tornados, Wasserhosen und Kleintromben" für die heutige Tornadoforschung (The relevance of Johannes P. Letzmann's "Guidelines for research on tornadoes, waterspouts, and whirlwinds" for contemporary tornado research). Meteorol. Z. 9, 165-174 [In German, available at essl. org/people/dotzek/]

Dotzek, N., Höller, H., Théry, C., Fehr, T., 2001. Lightning evolution related to radar-derived microphysics in the 21 July 1998 EULINOX supercell storm. Atmos. Res. 56, 335-354.

Dotzek, N., Grieser, J., Brooks, H.E., 2003. Statistical modeling of tornado intensity distributions. Atmos. Res. 67-68, 163-187.

Dotzek, N., Kurgansky, M.V., Grieser, J., Feuerstein, B., Névir, P., 2005. Observational evidence for exponential tornado intensity distributions over specific kinetic energy. Geophys. Res. Lett. 32, L24813. doi:10.1029/ 2005GL024583.

Dotzek, N., Lang, P., Hagen, M., Fehr, T., Hellmiss, W., 2007. Doppler radar observation, CG lightning activity, and aerial survey of a multiple downburst in southern Germany on 23 March 2001. Atmos Res. 83, 519-533.

Dotzek, N., Peterson, R.E., Feuerstein, B., Hubrig, M., 2008. Comments on "A simple model for simulating tornado damage in forests". J. Appl. Meteorol. Climatol. 47, 726-731.

Dotzek, N., Groenemeijer, P., Feuerstein, B., Holzer, A.M., 2009. Overview of ESSL's severe convective storms research using the European Severe Weather Database ESWD. Atmos. Res. 93, 575-586 (this volume).

Emanuel, K.A., 1994. Atmospheric Convection. Oxford University Press, New York. 883 pp. 
Faust, H., 1948. Untersuchungen von Forstschäden hinsichtlich der Windstruktur bei einer Bö (Investigation of forest damage with regard to the wind structure in a squall). Meteorol. Rundsch. 1, 290-297 [In German].

Fehr, T., Dotzek, N., Höller, H., 2005. Comparison of lightning activity and radar-retrieved microphysical properties in EULINOX storms. Atmos. Res. 76, 167-189.

Feuerstein, B., Dotzek, N., Grieser, J., 2005. Assessing a tornado climatology from global tornado intensity distributions. J. Climate 18, 585-596.

Freuer, C., 2002: Bemerkungen zur prognostischen Erfassung der Unwetter vom 19./20.6 sowie 23./24.6.2002 (Remarks on the prognostic coverage of the severe storms of 19-20 June and 23-24 June 2002). DWD RZ Munich, 25 June 2002, unpublished manuscript, 5 pp.

Friedrich, K., 2002: Determination of three-dimensional wind-vector fields using a bistatic Doppler radar network. Ph. D. thesis, Univ. Munich, 129 pp.

Friedrich, K., Hagen, M., 2004. Evaluation of wind vectors measured by a bistatic Doppler radar network. J. Atmos. Ocean. Technol. 21, 1840-1854.

Friedrich, K., Caumont, O., 2004. Dealiasing Doppler velocities measured by a bistatic radar network during a downburst-producing thunderstorm. J. Atmos. Ocean. Technol. 21, 717-729.

Fujita, T.T., 1971. Proposed characterization of tornadoes and hurricanes by area and intensity. SMRP research paper no. 91. University of Chicago. 42 pp.

Fujita, T.T., 1981. Tornadoes and downbursts in the context of generalized planetary scales. J. Atmos. Sci. 38, 1511-1534.

Fujita, T.T., 1985. The downburst - microburst and macroburst. SMRP research paper no. 210. Univ. Chicago. $122 \mathrm{pp}$.

Fujita, T.T., Pearson, A.D., 1973. Results of FPP classification of 1971 and 1972 tornadoes. Preprints, 8th Conf. on Severe Local Storms, Denver. Amer. Meteor. Soc., Boston, pp. 142-145.

Fujita, T.T., McCarthy, J., 1990. In: Atlas, D. (Ed.), The application of weather radar to aviation meteorology. Radar in Meteorology, vol. 657-681. Amer. Meteor. Soc., Boston. 806 pp.

Gatzen, C., 2004. A derecho in Europe: Berlin, 10 July 2002. Wea. Forecasting 19, 639-645.

Geerts, B., 2001. Estimating downburst-related maximum surface wind speeds by means of proximity soundings in New South Wales, Australia. Wea. Forecasting 16, 261-269.

Heimann, D., Kurz, M., 1985. The Munich hailstorm of July 12, 1984 - a discussion of the synoptic situation. Beitr. Phys. Atmos. 58, 528-544.

Höller, H., 1994. Mesoscale organization and hailfall characteristics of deep convection in southern Germany. Beitr. Phys. Atmos. 67, 219-234.

Höller, H., 1995. Radar-derived mass-concentrations of hydrometeors for cloud model retrievals. Proc., 27th Conf. on Radar Meteor., Vail, 9-13 October 1995. Amer. Meteor. Soc., Boston, pp. 453-454.

Höller, H., Reinhardt, M.E., 1986. The Munich hailstorm of July 12, 1984 convective development and preliminary hailstone analysis. Beitr. Phys. Atmos. 59, 1-12.

Höller, H., Bringi, V.N., Hubbert, J., Hagen, M., Meischner, P.F., 1994. Life cycle and precipitation formation in a hybrid-type hailstorm revealed by polarimetric and Doppler radar measurements. J. Atmos. Sci. 51, 2500-2522.

Houze, R.A., 1993. Cloud dynamics. Int. Geophys. Ser., vol. 53. Acad. Press, San Diego. 570 pp.

Hubrig, M., 2004. Analyse von Tornado- und Downburst-Windschäden an Bäumen (Analysis of tornado and downburst wind damage to trees). Forst Holz 59, 78-84 [In German, available at tordach.org].

Kamburova, P.L., Ludlam, F.H., 1966. Rainfall evaporation in thunderstorm downdraughts. Quart. J. Roy. Meteor. Soc. 92, 510-518.
Koschmieder, H., 1944. Über Böen (On squalls). Meteorol. Z. 61, 244-247.

Letzmann, J. P., 1939: Richtlinien zur Erforschung von Tromben, Tornados, Wasserhosen und Kleintromben (Guidelines for research on tornadoes, waterspouts, and whirlwinds). Int. Meteor. Org., Klimatol. Komm., Protokolle der Tagung in Salzburg, 13.-17. September 1937, Publ. 38, Leyden, Anlage XI, 91-110 [In German, available at tordach.org].

Markowski, P.M., 2002. Hook echoes and rear-flank downdrafts: a review. Mon. Weather Rev. 130, 852-876.

McCann, D.W., 1994. WINDEX - a new index for forecasting microburst potential. Wea. Forecasting 9, 532-541.

Meischner, P.F., Bringi, V.N., Heimann, D., Höller, H., 1991. A squall line in southern Germany: kinematics and precipitation formation as deduced by advanced polarimetric and Doppler radar measurements. Mon. Weather Rev. 119, 678-701.

Peterson, R.E., 1992a. Johannes Letzmann: a pioneer in the study of tornadoes. Wea. Forecasting 7, 166-184.

Peterson, R.E., 1992b. Letzmann's and Koschmieder's "Guidelines for research on funnels, tornadoes, waterspouts and whirlwinds". Bull. Am. Meteorol. Soc. 73, 597-611.

Roach, W.T., Findlater, J., 1983. An aircraft encounter with a tornado. Meteorol. Mag. 112, 29-49.

Scharfenberg, K.A., 2002. Polarimetric radar observations of a microburstproducing thunderstorm during STEPS. Preprints, 21st Conf. on Severe Local Storms, San Antonio, 12-16 August 2002. Amer. Meteor. Soc. Boston, pp. 74-77.

Scharfenberg, K.A., 2003. Polarimetric radar signatures of microburstproducing thunderstorms. Preprints, 31st Conf. on Radar Meteor., Seattle, 6-12 August 2003. Amer. Meteor. Soc., Boston, pp. 581-584.

Schroth, A.C., Chandra, M.S., Meischner, P., 1988. A C-band coherent polarimetric radar for propagation and cloud physics research. J. Atmos. Ocean. Technol. 5, 803-822.

Snow, J.T. (Ed.), 2001. Proceedings of the Conference on European Tornadoes and Severe Storms, Toulouse, 1-4 February 2000. Atmos. Res., vol. 56. 409 pp.

Snow, J.T. (Ed.), 2003. Proceedings of the European Conference on Severe Storms, Prague, 26-30 August 2002. Atmos. Res., vol. 67-68. 704 pp.

Srivastava, R.C., 1985. A simple model of evaporatively driven downdraft: application to microburst downdraft. J. Atmos. Sci. 42, 1004-1023.

Srivastava, R.C., 1987. A model of intense downdrafts driven by the melting and evaporation of precipitation. J. Atmos. Sci. 44, 1752-1773.

Suckstorff, G.A., 1935. Die Strömungsvorgänge in Instabilitätsschauern (The flow processes in showers caused by instability). Meteorol. Z. 52, 449-452 [In German].

Suckstorff, G.A., 1938. Kaltlufterzeugung durch Niederschlag (Cold air generation by precipitation). Meteorol. Z. 55, 287-292 [In German].

Vivekanandan, J., Bringi, V.N., Raghavan, R., 1990. Multiparameter radar modeling and observations of melting ice. J. Atmos. Sci. 47, 549-564.

Wakimoto, R.M., 2001. Convectively driven high wind events. Meteorol. Monogr. 28 (50), 255-298.

Wakimoto, R.M., Bringi, V.N., 1988. Dual-polarization observations of microbursts associated with intense convection: the 20 July storm during the MIST project. Mon. Weather Rev. 116, 1521-1539.

Wegener, A., 1917. Wind- und Wasserhosen in Europa (Tornadoes in Europe). Verlag Friedrich Vieweg und Sohn, Braunschweig. 301 pp. [In German, available at essl.org].

Zrnić, D.S., Keenan, T.D., Carey, L.D., May, P., 2000. Sensitivity analysis of polarimetric variables at a 5-cm wavelength in rain. J. Appl. Meteorol. 39, 1514-1526. 